\title{
Spatial distribution of aerosol microphysical and optical properties and direct radiative effect from the China Aerosol Remote Sensing Network
}

\author{
Huizheng Che ${ }^{1}$, Xiangao Xia ${ }^{2,3}$, Hujia Zhao ${ }^{1,4}$, Oleg Dubovik ${ }^{5}$, Brent N. Holben ${ }^{6}$, Philippe Goloub ${ }^{5}$, \\ Emilio Cuevas-Agulló ${ }^{7}$, Victor Estelles ${ }^{8}$, Yaqiang Wang ${ }^{1}$, Jun Zhu ${ }^{9}$, Bing Qi ${ }^{10}$, Wei Gong ${ }^{11}$, Honglong Yang ${ }^{12}$, \\ Renjian Zhang ${ }^{13}$, Leiku Yang ${ }^{14}$, Jing Chen ${ }^{15}$, Hong Wang ${ }^{1}$, Yu Zheng ${ }^{1}$, Ke Gui ${ }^{1}$, Xiaochun Zhang ${ }^{16}$, and \\ Xiaoye Zhang ${ }^{1}$ \\ ${ }^{1}$ State Key Laboratory of Severe Weather (LASW) and Key Laboratory of Atmospheric Chemistry (LAC), Chinese Academy \\ of Meteorological Sciences, CMA, Beijing, 100081, China \\ ${ }^{2}$ Laboratory for Middle Atmosphere and Global Environment Observation (LAGEO), Institute of Atmospheric Physics, \\ Chinese Academy of Sciences, Beijing, 100029, China \\ ${ }^{3}$ School of the Earth Science, University of Chinese Academy of Science, Beijing, 100049, China \\ ${ }^{4}$ Environmental and Meteorological Department, Institute of Atmospheric Environment, CMA, Shenyang, 110016, China \\ ${ }^{5}$ Laboratoire d'Optique Amosphérique, Université des Sciences et Technologies de Lille, 59655, Villeneuve d'Ascq, France \\ ${ }^{6}$ NASA Goddard Space Flight Center, Greenbelt, MD, USA \\ ${ }^{7}$ Centro de Investigación Atmosférica de Izaña, AEMET, 38001 Santa Cruz de Tenerife, Spain \\ ${ }^{8}$ Dept. Fisica de la Terra i Termodinamica, Universitat de València, C/ Dr. Moliner 50, 46100 Burjassot, Spain \\ ${ }^{9}$ Collaborative Innovation Center on Forecast and Evaluation of Meteorological Disasters, Nanjing University of Information \\ Science \& Technology, Nanjing, 210044, China \\ ${ }^{10}$ Hangzhou Meteorological Bureau, Hangzhou, 310051, China \\ ${ }^{11}$ State Key Laboratory of Information Engineering in Surveying, Mapping and Remote Sensing, \\ Wuhan University, Wuhan, 430079, China \\ ${ }^{12}$ Shenzhen Meteorological Bureau, Shenzhen, 518040, China \\ ${ }^{13}$ Key Laboratory of Regional Climate-Environment Research for Temperate East Asia, Institute of Atmospheric Physics, \\ Beijing, 100029, China \\ ${ }^{14}$ School of Surveying and Land Information Engineering, Henan Polytechnic University, Jiaozuo, 454000, China \\ ${ }^{15}$ Shijiazhuang Meteorological Bureau, Shijiazhuang, 050081, China \\ ${ }^{16}$ Meteorological Observation Center, CMA, Beijing, 100081, China
}

Correspondence: Huizheng Che (chehz@cma.gov.cn) and Xiaoye Zhang (xiaoye@cma.gov.cn)

Received: 27 April 2019 - Discussion started: 28 May 2019

Revised: 11 August 2019 - Accepted: 23 August 2019 - Published: 24 September 2019

\begin{abstract}
Multi-year observations of aerosol microphysical and optical properties, obtained through ground-based remote sensing at 50 China Aerosol Remote Sensing Network (CARSNET) sites, were used to characterize the aerosol climatology for representative remote, rural, and urban areas over China to assess effects on climate. The annual mean effective radii for total particles $\left(R_{\text {effT }}\right)$ decreased from north to south and from rural to urban sites, and high total particle volumes were found at the urban sites. The aerosol op-
\end{abstract}

tical depth at $440 \mathrm{~nm}\left(\mathrm{AOD}_{440 \mathrm{~nm}}\right)$ increased from remote and rural sites (0.12) to urban sites (0.79), and the extinction Ångström exponent (EAE $440-870 \mathrm{~nm})$ increased from 0.71 at the arid and semi-arid sites to 1.15 at the urban sites, presumably due to anthropogenic emissions. Singlescattering albedo $\left(\mathrm{SSA}_{440 \mathrm{~nm}}\right)$ ranged from 0.88 to 0.92 , indicating slightly to strongly absorbing aerosols. Absorption $\mathrm{AOD}_{440 \mathrm{~nm}}$ values were 0.01 at the remote sites versus 0.07 at the urban sites. The average direct aerosol radiative ef- 
fect (DARE) at the bottom of atmosphere increased from the sites in the remote areas $\left(-24.40 \mathrm{~W} \mathrm{~m}^{-2}\right)$ to the urban areas $\left(-103.28 \mathrm{~W} \mathrm{~m}^{-2}\right)$, indicating increased cooling at the latter. The DARE for the top of the atmosphere increased from $-4.79 \mathrm{~W} \mathrm{~m}^{-2}$ at the remote sites to $-30.05 \mathrm{~W} \mathrm{~m}^{-2}$ at the urban sites, indicating overall cooling effects for the Earth-atmosphere system. A classification method based on $\mathrm{SSA}_{440 \mathrm{~nm}}$, fine-mode fraction (FMF), and $\mathrm{EAE}_{440-870 \mathrm{~nm}}$ showed that coarse-mode particles (mainly dust) were dominant at the rural sites near the northwestern deserts, while light-absorbing, fine-mode particles were important at most urban sites. This study will be important for understanding aerosol climate effects and regional environmental pollution, and the results will provide useful information for satellite validation and the improvement of climate modelling.

\section{Introduction}

Atmospheric aerosols have important direct effects on climate because they can scatter and absorb radiant energy and, in so doing, affect the Earth's energy balance (Charlson et al., 1992; Yang et al., 2016). Meanwhile, the aerosols can serve as cloud condensation nuclei or ice nuclei to affect the climate indirectly through aerosol-cloud interactions (Twomey et al., 1984; Garrett and Zhao, 2006; Zhao et al., 2015; Xie et al., 2013). The optical properties of the aerosol determine the particles' direct effects on the Earth's radiative balance and weather-climate change (Ramanathan et al., 2001; Eck et al., 2005; Myhre, 2009; Zhao et al., 2018; Che et al., 2019a; Li et al., 2016). Aerosol optical depth (AOD) is one of the key measures of the total aerosol extinction effects on climate (Breon et al., 2002), and the extinction Ångström exponent (EAE), with spectral dependence, can be used to obtain the information about aerosol size distributions (Gobbi et al., 2007; Eck et al., 1999; Zheng et al., 2017). The aerosols' absorptivity depends on particle composition and is a key determinant to calculate the direct aerosol radiative effect (Haywood and Shine, 1995; Li et al., 2016), and the singlescattering albedo (SSA) is a parameter that has the spectral dependence to distinguish major aerosol particle types (Jacobson et al., 2000; Dubovik et al., 2002; Gelencser, 2004; Russell et al., 2010; Giles et al., 2012).

With the recognition of the importance for climate, the aerosol optical properties have been obtained from ground-based monitoring networks worldwide; some of the major networks include, the Aerosol Robotic Network (AERONET; Holben et al., 1998) and its sub-networks, the PHOtométrie pour le Traitement Opérationnel de Normalisation Satellitaire (PHOTONS), the Canadian Sun Photometer Network (AEROCAN), and the Iberian Network for aerosol measurements (RIMA; Goloub et al., 2007; Bokoye et al., 2001; Prats et al., 2011); the SKYrad Network (SKYNET; Takamura and Nakajima, 2004; Che et al., 2008); the Eu- ropean aerosol Lidar Network (EARLINET; Pappalardo et al., 2014); and the Global Atmosphere Watch ProgrammerPrecision Filter Radiometers network (GAW-PFR; Wehrli, 2002; Estellés et al., 2012). The China Aerosol Remote Sensing NETwork (CARSNET), the Chinese Sun Hazemeter Network (CSHNET), and the Sun-Sky Radiometer Observation Network (SONET) have been established to measure aerosol optical properties in China (Che et al., 2009a, 2015; Xin et al., 2007, 2015; Li et al., 2018). Furthermore, aerosol optical properties have also been used in comprehensive studies of aerosol physical characteristics and chemical composition in many regions of China (Che et al., 2009c, 2018; Zhao et al., 2018).

China has become one of the largest aerosol sources in the world associated with its rapid economic development, and this has caused significant effects on local environments and regional climate (Che et al., 2005; Xia, 2010; Li et al., 2016; Yang et al., 2018, 2019b; Zhao et al., 2019; Gui et al., 2019). There have been numerous studies that have focused on aerosol optical properties obtained though groundbased remote-sensing methods in China (Luo et al., 2002; Li et al., 2003; Duan and Mao, 2007). Some previous research has paid more attention to aerosol's optical properties and its radiative effects over the urban industrial areas, as well as at coastal sites in northeastern and eastern China (Wang et al., 2010; Xin et al., 2011; Xia et al., 2007; Zhao et al., 2016; Wu et al., 2012; Shen et al., 2019). Many studies of aerosol optical properties were conducted in northern China with high aerosol loadings, such as the Beijing-Tianjin-Hebei region (Che et al., 2014; Xia et al., 2013; Fan et al., 2006; Xie et al., 2008; Zhang et al., 2019; Yang et al., 2019a; Zhao et al., 2018; Zheng et al., 2019). Aerosol optical properties have also been investigated at Hefei, Shouxian, Nanjing, Taihu, Shanghai, and other sites in eastern China (Lee et al., 2010; He et al., 2012; Zhuang et al., 2014; Z. Wang et al., 2015; Che et al., 2018). Some studies of aerosol optical properties have been made in southern and central China (L. C. Wang et al., 2015; Tao et al., 2014b), and those at remote and rural sites in China provide information on regional background conditions (Che et al., 2009b; Wang et al., 2010; Zhu et al., 2014; Yuan et al., 2014).

China's vast size, varied terrain, and heterogeneity of aerosol sources has led to strong temporal and spatial variability in aerosol optical and physical properties. The mixtures of aerosol types at most sites are complex, and aerosol populations' sizes and compositions are affected by their sources, transformations that occur during transportation, and removal processes (Cao et al., 2007; Wang et al., 2007; Zhang et al., 2013; Wan et al., 2015). National-scale, groundbased measurements of aerosol microphysical and optical properties obtained from the sun photometer provide a better understanding of the aerosols' climate effects over the different regions of China. The measurements of greatest interest include aerosol size distributions (volume and aerosol effective radii) and optical properties (AOD, AE, SSA, absorption 
AOD) because those data can be used to evaluate aerosol direct radiative effect.

The aim of this study was focused on the investigation of the climatological spatial distribution of aerosol microphysical and optical properties over regional scales using spatial distribution data from the national CARSNET network. The data were collected at CARSNET sites, which includes sites in remote, rural, and urban areas, with the same calibration procedures and calculation algorithms used at all sites. As a result, the data are directly comparable among sites (Che et al., 2009a), and the results can be used to characterize the regional distribution and temporal variation in aerosol optical properties. This research focused on aerosol climate effects and regional environmental pollution, and the results should be useful for satellite validations and for the improvement of models in the future. The remainder of this paper is organized as follows: firstly, Sect. 2 describes the sites in detail and then introduces the methods for the data processing of the aerosol optical properties and the direct aerosol radiative effect calculation, through the retrieved aerosol optical parameters. Section 3 illustrates the aerosol microphysical and optical properties, as well as its direct aerosol radiative effect. An aerosol type classification method is proposed according to the aerosol optical parameters. Section 4 presents the conclusions of the study.

\section{Site description, instruments, and data}

\subsection{Site description}

Sun photometers (CE-318, Cimel Electronique, Paris, France; see Appendix A) were installed at 50 CARSNET sites (Fig. 1) from 2010 to 2017. The stations were classified as remote, rural, or urban sites based on administrative division (Appendix Table A1). Three of the remote stations were more than $3000 \mathrm{~m}$ above sea level on the Tibetan Plateau, far from the anthropogenic influences, and one of them was a northwestern regional background site in China. The 23 rural sites represent (i) 5 sites of desert regions affected by mostly dust aerosols rather than anthropogenic particles, (ii) 2 sites affected by both dust and anthropogenic activities on the Loess Plateau, and (iii) 16 sites located near or surrounding large cities with relatively strong impacts from anthropogenic activities in central and eastern China. The last category is 24 urban sites located in provincial capitals or heavily populated cities.

\subsection{Instruments and calibration}

The CE-318 sun photometers used in this study were calibrated annually, using the CARSNET calibration protocol, to verify the accuracy and reliability of the sky irradiance measurements (Holben et al., 1998; Che et al., 2009a; Tao et al., 2014a). The reference instruments for CARSNET were periodically calibrated at Izaña, Tenerife, Spain, lo- cated at $28.31^{\circ} \mathrm{N}, 16.50^{\circ} \mathrm{W}(2391.0 \mathrm{~m}$ a.s.1.), in conjunction with the AERONET program. There are several different types of Cimel instruments that have been used at the 50 sites in this network: (1) logical type CE-318 sun photometers $(440,675,870,940,1020$, and three polarization bands at $870 \mathrm{~nm}$ ), (2) numerical type CE-318 sun photometers $(440,675,870,940,1020 \mathrm{~nm}$, and three polarization bands at $870 \mathrm{~nm}$ ), (3) numerical type CE-318 sun photometers at eight wavelengths $(340,380,440,500,675,870,940$, and $1020 \mathrm{~nm}),(4)$ and numerical-type CE-318 sun photometers at nine wavelengths $(340,380,440,500,675,870,940,1020$, and $1640 \mathrm{~nm}$ ).

Measurements used to retrieve AODs were at 340, 380, $440,500,675,870,1020$, and $1640 \mathrm{~nm}$, while the total precipitable water content was obtained by using those measurements at $940 \mathrm{~nm}$ (Holben et al., 1998; Dubovik and King, 2000). The cloud-screened AOD data were calculated by using the ASTPwin software, and extinction Ångström exponents (EAE) were calculated from the instantaneous AODs for wavelengths of 440 and $870 \mathrm{~nm}$ (Che et al., 2009a, 2015). Sites with more than three daily AOD observations and more than 10 monthly AOD observation days were used to calculate the daily and monthly mean AODs and extinction Ångström exponents. The fine-mode fraction (FMF) is described as the fraction of fine-mode particles of total $\mathrm{AOD}_{440 \mathrm{~nm}}\left(\mathrm{AOD}_{\text {fine }} 440 \mathrm{~nm} / \mathrm{AOD}_{440 \mathrm{~nm}}\right)$.

\subsection{Data processing}

The aerosol microphysical and optical properties, including volume size distributions $(\mathrm{d} V(r) / \mathrm{d} \ln r)$; the total, fine, and coarse-mode aerosol effective radii ( $R_{\text {effT }}, R_{\text {effF }}$, and $R_{\text {effC }}$, respectively); single-scattering albedo (SSA); complex refractive indices; absorption AODs (AAODs); and absorption Ångström exponents (AAEs), were retrieved from the observational data from the sky scattering channel of the sun photometers at 440, 670, 870, and $1020 \mathrm{~nm}$ using the algorithms of Dubovik et al. (2002, 2006). In the process of retrieval, the data of surface albedo (SA) was interpolated or extrapolated to $440,670,870$, and $1020 \mathrm{~nm}$ based on the daily MCD43C3 data, a product from the MODIS-Moderate Resolution Imaging Spectroradiometer surface reflectance (https://ladsweb. modaps.eosdis.nasa.gov/, last access: 31 March 2019). The algorithm used to calculate aerosol volume size distributions $(\mathrm{d} V(r) / \mathrm{d} \ln r)$ was under the assumption of a homogeneous distribution of non-spherical particles following the approach of Dubovik et al. (2006). The sphericity fraction retrieved from the inversions is defined as spherical particles/(spheroidal particles + spherical particles) (Giles et al., 2011).

Dubovik et al. $(2002,2006)$ defined that all the particles with effective radii $<0.992 \mu \mathrm{m}$ were considered fine-mode particles, and those $>0.992 \mu \mathrm{m}$ were considered coarse-mode particles. For the total ( $\left.R_{\text {eff }}\right)$, fine-mode $\left(R_{\text {effF }}\right)$, and coarsemode $\left(R_{\text {effC }}\right)$ aerosols, the effective radii are calculated by 


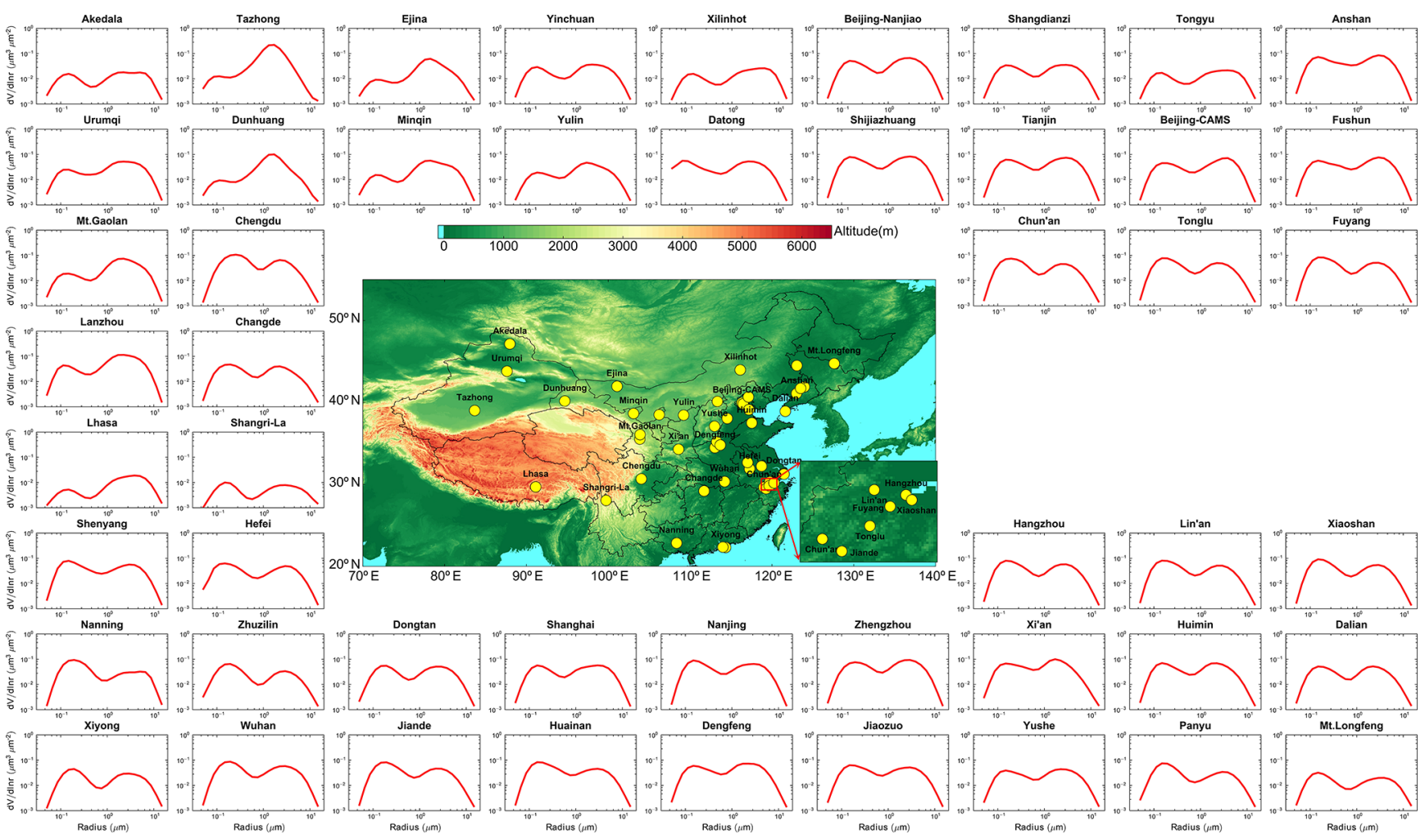

Figure 1. Annual spatial distribution of aerosol volume-size distributions at the CARSNET sites.

the following equation:

$$
R_{\mathrm{eff}}=\frac{\int_{r_{\min }}^{r_{\max }} r^{3} \frac{\mathrm{d} N(r)}{\mathrm{d} \ln r} \mathrm{~d} \ln r}{\int_{r_{\min }}^{r_{\max }} r^{2} \frac{\mathrm{d} N(r)}{\mathrm{d} \ln r} \mathrm{~d} \ln r},
$$

where $r_{\min }$ denotes $0.05,0.05$, and $0.992 \mu \mathrm{m}$ and $r_{\max }$ denotes $15,0.992$, and $15 \mu \mathrm{m}$ of the total, fine-mode, and coarse-mode particles, respectively.

The coarse $\left(\mathrm{PV}_{\mathrm{C}}\right)$ and fine aerosol particle volumes distributions $\left(\mathrm{PV}_{\mathrm{F}}\right)$ are calculated according to a bimodal lognormal function described by Whitey (1978), Shettle and Fenn (1979), and Remer and Kaufman (1998):

$$
\frac{\mathrm{d} V(r)}{\mathrm{d} \ln r}=\sum_{i=1}^{2} \frac{C_{\mathrm{v}, i}}{\sqrt{2 \pi} \sigma_{i}} \exp \left[-\frac{\left(\ln r-\ln r_{V, i}\right)^{2}}{2 \sigma_{i}^{2}}\right],
$$

where $C_{\mathrm{v}, i}$ is the volume concentration, $r_{V, i}$ is the median radius, and $\sigma_{i}$ is the standard deviation.

The volume median radius is computed by fine-mode and coarse-mode particles as follows:

$$
\ln r_{\mathrm{V}}=\frac{\int_{r_{\min }}^{r_{\max }} \ln r \frac{\mathrm{d} V(r)}{\mathrm{d} \ln r} \mathrm{~d} \ln r}{\int_{r_{\min }}^{r_{\max }} \frac{\mathrm{d} V(r)}{\mathrm{d} \ln r} \mathrm{~d} \ln r} .
$$

Then the standard deviation is calculated from the volume median radius:

$\sigma_{V}=\sqrt{\frac{\int_{r_{\min }}^{r_{\max }}\left(\ln r-\ln r_{V}\right)^{2} \frac{\mathrm{d} V(r)}{\mathrm{d} \ln r} \mathrm{~d} \ln r}{\int_{r_{\min }}^{r_{\max } \mathrm{d} V(r)} \mathrm{d} \ln r} \mathrm{~d} \ln r}$.

The volume concentration $\left(\mu \mathrm{m}^{3}\right.$ per $\left.\mu \mathrm{m}^{2}\right)$ is speculated by the following equation:

$C_{V}=\int_{r_{\min }}^{r_{\max }} \frac{\mathrm{d} V(r)}{\mathrm{d} \ln r} \mathrm{~d} \ln r$.

The SSA was retrieved only for $\mathrm{AOD}_{440 \mathrm{~nm}}>0.40$; this was done to avoid the larger uncertainty inherent in the lower AOD retrieval, according to Dubovik et al. (2002, 2006). The AAOD and AAE for wavelength $\lambda$ were calculated as follows:

$$
\begin{aligned}
& \operatorname{AAOD}(\lambda)=[1-\operatorname{SSA}(\lambda)] \times \operatorname{AOD}(\lambda), \\
& \operatorname{AAE}=\frac{-\mathrm{d} \ln [\operatorname{AAOD}(\lambda)]}{\mathrm{d} \ln (\lambda)} .
\end{aligned}
$$

The total AODs' uncertainty was 0.01 to 0.02 according to Eck et al. (1999). The accuracy of SSA retrieved from $\mathrm{AOD}_{440 \mathrm{~nm}}>0.50$ with a solar zenith angle of $>50$ was 0.03 (Dubovik et al., 2002). The accuracy of the particle volume size distribution was $15 \%-25 \%$ between $0.1 \mu \mathrm{m} \leq r \leq$ $7.0 \mu \mathrm{m}$ and $25 \%-100 \%$ when $r<0.1 \mu \mathrm{m}$ and $r>7 \mu \mathrm{m}$. 
Direct aerosol radiative effect (DARE in $\mathrm{W} \mathrm{m}^{-2}$ ) was calculated by the radiative transfer module under cloud-free conditions, which is similar to the inversion of AERONET (García et al., 2008, 2012). The DARE at the bottom of the atmosphere (BOA) and the top of the atmosphere (TOA) was defined as the difference in the shortwave radiative fluxes with and without aerosol effects as follows:

$\operatorname{DARE}_{\mathrm{TOA}}=F_{\mathrm{TOA}}^{\uparrow 0}-F_{\mathrm{TOA}}^{\uparrow}$,
DARE $_{\mathrm{BOA}}=F_{\mathrm{BOA}}^{\downarrow}-F_{\mathrm{BOA}}^{\downarrow 0}$,

where $F$ and $F^{0}$ denote the broadband fluxes of including and excluding aerosols, respectively, at the BOA and TOA. The " $\uparrow "$ and " $\downarrow$ "mean the upward fluxes and downward fluxes, respectively.

In the radiative transfer module, the absorption and multiple scattering effects are taken into account during flux calculations using the discrete ordinates (DISORT) approach (Nakajima and Tanaka, 1988; Stamnes et al., 1988). Gaseous distributions and single fixed aerosol vertical distributions (exponential to $1 \mathrm{~km}$ ), taken from the multilayered US standard 1976 atmosphere, were used in the radiative flux calculations (García et al., 2008). García et al. (2008) pointed out that the error for the observed solar radiation at the surface in global was $+2.1 \pm 3.0 \%$ for an overestimation of about $+9 \pm 12 \mathrm{Wm}^{-2}$. The data used in preparing the figures for the present paper have been made available as an Appendix.

\section{Results and discussion}

\subsection{Spatial distribution of aerosol microphysical properties}

A map showing the 50 CARSNET sampling sites and plots of the aerosol volume size distributions $(\mathrm{d} V(r) / \mathrm{d} \ln r)$ at each of the sites is shown in Fig. 1. Generally, the annual mean effective radius of total particles $\left(R_{\mathrm{effT}}\right)$ decreased from the inland northwestern areas to the southeastern coastal areas. Furthermore, the volume concentration of total particles was found to be substantially higher at the urban sites. The volume of the coarse-mode particles was considerably larger than that of the fine-mode particles at the remote, arid, and semi-arid sites and at those sites on the Chinese Loess Plateau (CLP) or nearby, indicating that those areas were most strongly affected by larger particles, most likely mineral dust, as discussed below.

The average (arithmetic mean) $R_{\text {effT }}$ at the remote sites was about $0.47 \mu \mathrm{m}$ with the volume about $0.05 \mu \mathrm{m}^{3}$ per $\mu \mathrm{m}^{2}$ (Table 1). A large $R_{\text {effT }}(0.64 \mu \mathrm{m})$ was found at Lhasa, and the total aerosol volume there was $0.05 \mu \mathrm{m}^{3}$ per $\mu \mathrm{m}^{2}$. These results are consistent with those reports by Li et al. (2018), who found high levels of coarse-mode particles at Lhasa due to the presence of mineral dust. The two other remote sites, Akedala and Shangri-La, had smaller average $R_{\text {effT }}$ values than Lhasa ( 0.36 and $0.39 \mu \mathrm{m}$, respectively), and corresponding volumes were 0.06 and $0.03 \mu \mathrm{m}^{3}$ per $\mu \mathrm{m}^{2}$. The average fine-mode effective radius $\left(R_{\mathrm{effF}}\right)$ was $0.14 \mu \mathrm{m}$ at the remote sites, and fine-mode particle fractional volume $\left(\mathrm{PV}_{\mathrm{F}}\right)$ was $0.01 \mu \mathrm{m}^{3}$ per $\mu \mathrm{m}^{2}$, while the average coarse-mode effective radii $\left(R_{\text {effC }}\right)$ was $2.35 \mu \mathrm{m}$ and the coarse-mode fractional volume $\left(\mathrm{PV}_{\mathrm{C}}\right)$ was $0.03 \mu \mathrm{m}^{3}$ per $\mu \mathrm{m}^{2}$. These findings indicated that the contribution of coarse-mode particles to the total volume of aerosol was larger at the remote sites. A study by Cong et al. (2009) at the remote Nam Co site on the Tibetan Plateau showed that dust particles mainly affected the site in spring, while anthropogenic aerosols were prevalent in the summer.

The average $R_{\text {effT }}$ at the arid and semi-arid sites $(0.55 \mu \mathrm{m})$ was larger than at the remote sites, and the total volume of aerosols at the arid and semi-arid sites was also large $\left(0.14 \mu \mathrm{m}^{3}\right.$ per $\left.\mu \mathrm{m}^{2}\right)$, nearly 3 times that at the remote sites. Large $R_{\text {effT }}$ values $(0.71 \mu \mathrm{m})$ were found at Tazhong, which is near the northwestern deserts, and the aerosol volume there was also high, $0.30 \mu \mathrm{m}^{3}$ per $\mu \mathrm{m}^{2}$. Large $\mathrm{PV}_{C}$ values were found at the arid and semi-arid sites $\left(0.05-0.27 \mu^{3}\right.$ per $\left.\mu \mathrm{m}^{2}\right)$. The arithmetic mean $R_{\text {effT }}(0.49 \mu \mathrm{m})$ at the rural sites on or near the CLP had total aerosol volumes $\left(0.15 \mu \mathrm{m}^{3}\right.$ per $\mu \mathrm{m}^{2}$ ) similar to those at the arid and semi-arid sites. These results also show a major contribution to the aerosol volumes by coarse-mode particles at the sites in or near the mineral dust source regions. Bi et al. (2011) similarly found that coarse particles dominated the volume-size distribution at the Semi-Arid Climate and Environment Observatory of Lanzhou University (SACOL) on the CLP.

Small $R_{\text {effT }}$ values $(0.33 \mu \mathrm{m})$ were found at the rural sites in eastern China, and relatively high aerosol volumes were observed there $\left(0.18 \mu \mathrm{m}^{3}\right.$ per $\left.\mu \mathrm{m}^{2}\right)$. In the Yangtze River Delta (YRD) region, the $R_{\text {effF }}$ was large range for 0.16 $0.17 \mu \mathrm{m}$, and the $\mathrm{PV}_{F}$ values were $0.12-0.13 \mu \mathrm{m}^{3}$ per $\mu \mathrm{m}^{2}$. At the Mt. Longfeng background site in northeastern China, the total particle volume was low $\left(0.08 \mu \mathrm{m}^{3}\right.$ per $\left.\mu \mathrm{m}^{2}\right)$, which is consistent with minimal anthropogenic influences and low aerosol loadings. Compared with the other sites, the urban areas had relatively low coarse-mode aerosol concentrations, but small particles were plentiful - the average $R_{\text {effT }}$ was $0.37 \mu \mathrm{m}$ and total volume was high at $0.21 \mu \mathrm{m}^{3}$ per $\mu \mathrm{m}^{2}$. The average $R_{\mathrm{effF}}$ of fine-mode particles at the urban sites was $0.16 \mu \mathrm{m}$ with a PV F $0.10 \mu \mathrm{m}^{3}$ per $\mu \mathrm{m}^{2}$ while the $R_{\text {effC }}$ was $2.22 \mu \mathrm{m}$ and $\mathrm{PV}_{C}$ was $0.11 \mu \mathrm{m}^{3}$ per $\mu \mathrm{m}^{2}$.

The effective radii and $\mathrm{PV}_{\mathrm{F}}$ values showed strong relationships with population density and vehicle emissions at the urban sites. High volumes of fine-mode particles occurred at the northeastern urban site of Shenyang $\left(R_{\mathrm{effT}}=0.16 \mu \mathrm{m}\right.$, $\mathrm{PV}_{\mathrm{F}}=0.12 \mu \mathrm{m}^{3}$ per $\mu \mathrm{m}^{2}$ ); at major cities in northern China, including Shijiazhuang $\left(R_{\mathrm{effT}}=0.16 \mu \mathrm{m}, \mathrm{PV}_{\mathrm{F}}=0.12 \mu \mathrm{m}^{3}\right.$ per $\left.\mu \mathrm{m}^{2}\right)$ and Zhengzhou $\left(R_{\mathrm{effT}}=0.18 \mu \mathrm{m}, \mathrm{PV}_{\mathrm{F}}=0.12 \mu \mathrm{m}^{3}\right.$ per $\left.\mu \mathrm{m}^{2}\right)$; at Chengdu, a city in the Sichuan Basin $\left(R_{\text {effT }}=\right.$ $0.21 \mu \mathrm{m}, \mathrm{PV}_{\mathrm{F}}=0.16 \mu \mathrm{m}^{3}$ per $\left.\mu \mathrm{m}^{2}\right)$; and in the urban regions of Nanning $\left(R_{\mathrm{effT}}=0.18 \mu \mathrm{m}, \mathrm{PV}_{\mathrm{F}}=0.13 \mu \mathrm{m}^{3}\right.$ per $\left.\mu \mathrm{m}^{2}\right)$ and 
Table 1. Aerosol type classification based on the optical properties.

\begin{tabular}{llll}
\hline Type & EAE & SSA & Absorbing properties and particle size \\
\hline I & EAE $>1.20$ & SSA $_{440 \mathrm{~nm}} \leq 0.85$ & fine-mode particles with highly absorbing properties \\
II & EAE $>1.20$ & $0.85 \leq \mathrm{SSA}_{440 \mathrm{~nm}}<0.90$ & fine-mode particles with moderately absorbing properties \\
III & EAE $>1.20$ & $0.90 \leq \mathrm{SSA}_{440 \mathrm{~nm}}<0.95$ & fine-mode particles with slightly absorbing properties \\
IV & EAE $>1.20$ & SSA $_{440 \mathrm{~nm}}>0.95$ & fine-mode particles with weakly absorbing properties \\
V & $0.60 \leq \mathrm{EAE}<1.20$ & SSA $_{440 \mathrm{~nm}} \leq 0.95$ & mixed absorbing particles \\
VI & $0.60 \leq \mathrm{EAE}<1.20$ & SSA $_{440 \mathrm{~nm}}>0.95$ & mixed slightly absorbing particles \\
VII & EAE $\leq 0.60$ & SSA $_{440 \mathrm{~nm}} \leq 0.95$ & coarse-mode particles with strongly absorbing properties (mainly dust) \\
VIII & AE $\leq 0.60$ & SSA $_{440 \mathrm{~nm}}>0.95$ & coarse-mode particles with weakly absorbing properties
\end{tabular}

Panyu $\left(R_{\text {eff }}=0.16 \mu \mathrm{m}, \mathrm{PV}_{\mathrm{F}}=0.10 \mu \mathrm{m}^{3}\right.$ per $\left.\mu \mathrm{m}^{2}\right)$ in southern China. Overall, these results show that the volumes of fine-mode particles increased at the urban sites where anthropogenic influences were most apparent.

Cheng et al. (2015) found different aerosol volume size distributions for dust and sea salt in Shanghai in eastern China, and they showed that their relative abundances varied with season and in response to local or long-range transport. Zhao et al. (2018) reported the effect of sea salt aerosol on the aerosol absorption and radiative effects in the coastal region over northeastern China. The particles' hygroscopic growth, with different compositions observed in special climatic conditions, could especially affect aerosol microphysical properties with their geographically variable effects (Zhang et al., 2015; Sun et al., 2010). Like in the YRD region, hygroscopic growth of fine-mode particles could lead to larger a AOD and the scattering enhancing reported by Sun et al. (2018) and Che et al. (2018). Xia et al. (2019) observed the aerosol hygroscopic growth of the fine particle scattering coefficient in Beijing.

\subsection{Spatial distributions of AOD and EAE}

The spatial distributions of $\mathrm{AOD}_{440 \mathrm{~nm}}$ and $\mathrm{EAE}_{440-870 \mathrm{~nm}}$ are shown in Fig. 2. The AOD $440 \mathrm{~nm}$ increased from the remote and rural sites to the urban sites, and as one might expect, the remote sites were the least affected by particle emissions and had the lowest aerosol loadings. For example, the AOD $440 \mathrm{~nm}$ at the remote stations was low and had an average value of 0.12 . The Lhasa and Shangri-La sites on the Tibetan Plateau had similar average $\mathrm{AOD}_{440 \mathrm{~nm}}$ values of 0.10 . These phenomena are similar to the study of Li et al. (2018), who showed clean air conditions at Lhasa with AOD $<0.1$. Cong et al. (2007, 2009) also found a low AOD (0.05) at Nam Co, which was comparable to the background levels at other remote sites.

The $\mathrm{AOD}_{440 \mathrm{~nm}}$ values at the arid and semi-arid sites and those on or near the Loess Plateau ranged from 0.32 to 0.42 , which is higher than at the remote sites. The high AOD $_{440 \mathrm{~nm}}$ at Tazhong (0.60), which is near the deserts in northwestern China, was likely due to the large aerosol volume of $0.30 \mu \mathrm{m}^{3}$ per $\mu \mathrm{m}^{2}$ (Sect. 3.1) caused by mineral dust. Indeed, arid and semi-arid regions in northwestern China are important sources of aeolian dust on a global scale (Bi et al., 2011). $\mathrm{Li}$ and Zhang (2012) showed that the contribution of dust to the average AOD at SACOL near Lanzhou was $28.4 \%$. Other sites that showed large $\mathrm{AOD}_{440 \mathrm{~nm}}$ include regions with strong anthropogenic influences, such as Dengfeng (0.79) on the North China Plain, Huimin (0.83) in the YRD (0.83 to 0.87), and Huainan (0.91) on the Guanzhong Plain.

Compared with the sites just discussed, lower AOD $_{440 \mathrm{~nm}}$ values were found at the Mt. Longfeng background station on the Northeast China Plain (0.34), the semi-arid rural site at Tongyu in northeastern China (0.23), and the clean Xiyong site in southern China (0.41). Zhu et al. (2014) found a low AOD of 0.28 at the North China Plain regional background site. Che et al. (2009c) pointed out that the large AOD at Lin'an was likely affected by the high aerosol loadings in YRD region. Among the urban sites in China, large $\mathrm{AOD}_{40 \mathrm{~nm}}$ values were found in the cities with strong influences of anthropogenic activities, such as the Northeast China Plain (Shenyang 0.89), North China Plain (Zhengzhou 0.99), central China (Wuhan 1.00) and Sichuan Basin (Chengdu 1.17); the average value for these sites was 0.79 . Lower $\mathrm{AOD}_{440 \mathrm{~nm}}$ values, that is $<0.50$, occurred at remote sites in northwestern China, including Ürümqi (0.42) and Yinchuan (0.37); these sites are less affected by industrial activities and the population densities are lower compared with the sites in northern or eastern China.

It is worth noting that the particle emissions in or around the urban sites could lead to large optical extinctions due to hygroscopic aerosol growth, especially in summer when the relative humidity is often high. In a related study, Zhang et al. (2018) found a large AOD of 1.10 at Wuhan in central China that was linked to secondary aerosol formation under the high summertime temperatures. Li et al. (2015) similarly concluded that high temperatures and humidity promoted the formation of fine particles and led to hygroscopic aerosol growth at Nanjing. Qin et al. (2017) observed a high $\mathrm{AOD}_{500 \mathrm{~nm}}$ of 1.04 at Shijiazhuang and related this to the hygroscopic growth of aerosol fine-mode particles during polluted days. 


\section{AODT distribution in China}

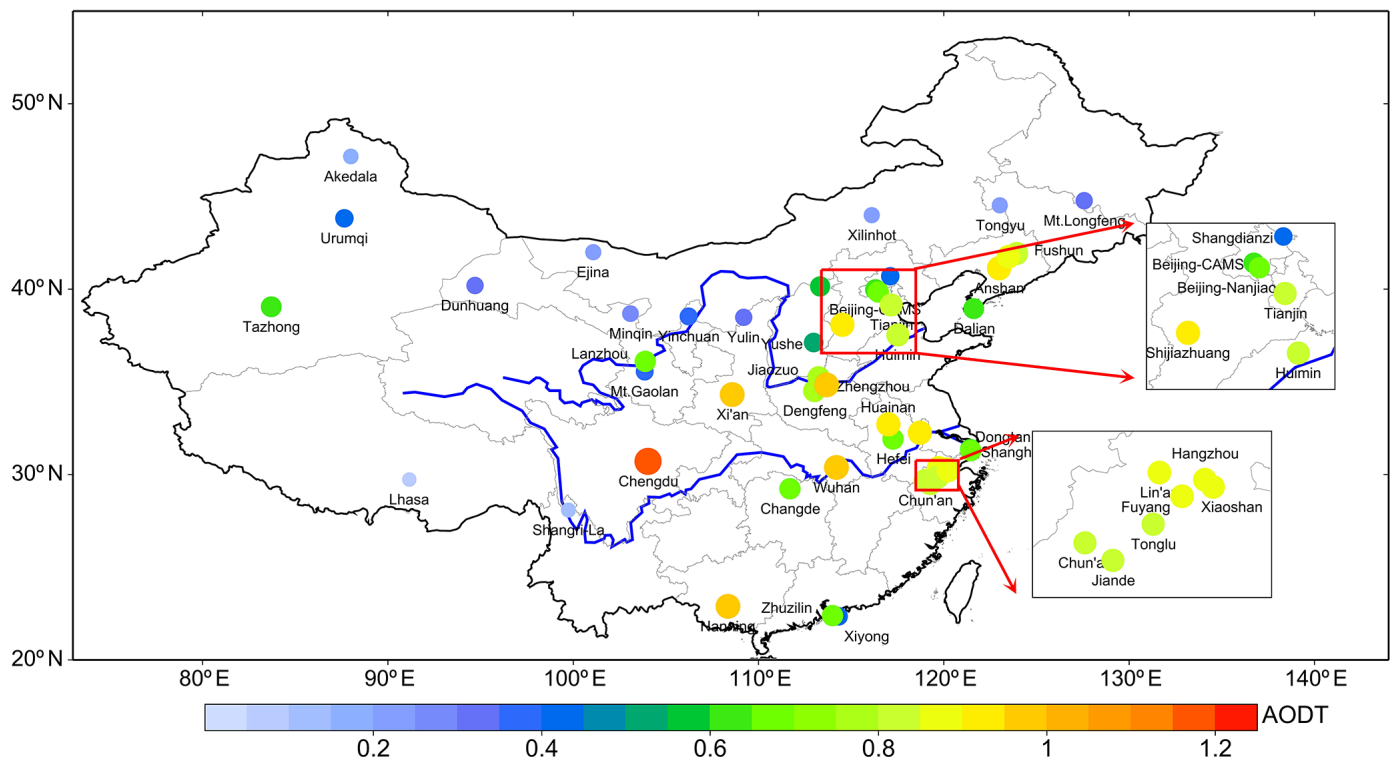

Figure 2. Annual spatial distribution of aerosol optical depth (AOD) at $440 \mathrm{~nm}$ at the CARSNET sites.

\section{EAE distribution in China}

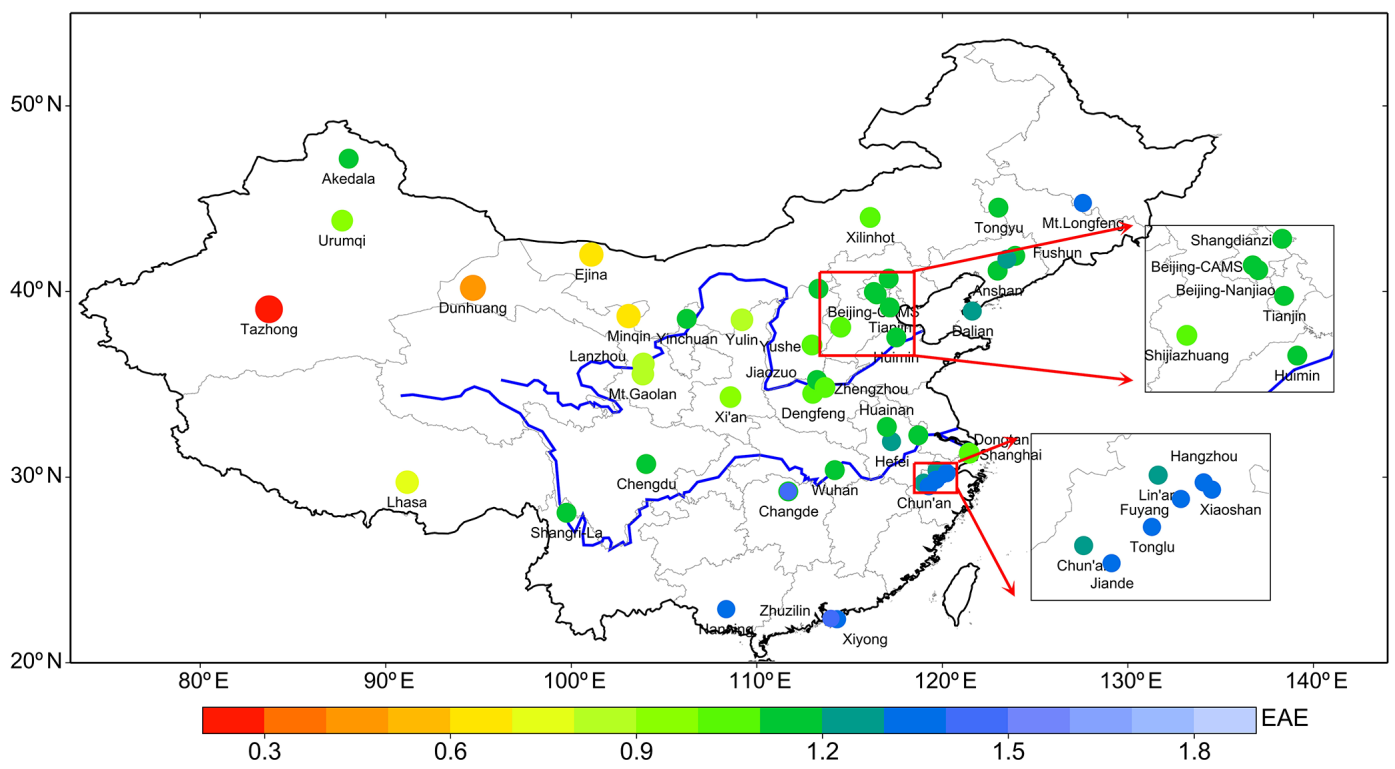

Figure 3. Annual spatial distribution of extinction Ångström exponent (AE) 440-870 nm at the CARSNET sites.

Clear spatial variability in EAE values over China is evident in Fig. 3, and at the remote sites the average EAEs were 1.03. The EAE at Lhasa (0.77) was lower than at Akedala $(\mathrm{EAE}=1.13)$, which is in an arid region of central Asia, or at Shangri-La $(E A E=1.19)$ in Tibet. The average coarse-mode average effective radius ( $R_{\text {effC }}$ ) at Lhasa was $2.26 \mu \mathrm{m}$ and the fractional volume was $0.04 \mu^{3}$ per $\mu \mathrm{m}^{2}$, this result suggests the major components of the large mineral dust particles in aerosol populations over that region. The smaller sphericity fraction $(\sim 42.70)$ and lower FMF $(0.66)$ at Lhasa indicates the presence of non-spherical aerosol coarse particles compared with the spherical fine particles in the urban sites.

At arid and semi-arid sites in China, the average EAE value (0.71) was relatively low and the FMF also was low (0.58). The EAE was extremely low at Tazhong (0.25), which is in the Taklamakan Desert in the Xinjiang Uygur Autonomous Region of northwestern China and the sphericity fraction (12.87) and FMF (0.35) there were lower compared with most of the other sites. This finding indicates a strong contribution of large particles in this desert region consistent 
with large volume of the coarse-mode particles $\left(0.27 \mu \mathrm{m}^{3}\right.$ per $\mu \mathrm{m}^{2}$ ) noted in Sect. 3.1. The average EAE reached 0.93 at the rural sites near the CLP, and the average value of FMF for those sites was 0.73 . Eck et al. (2005) found especially low EAE values in March and April (0.3 and 0.4, respectively) at Yulin, China, where the dust aerosol dominated the optical column.

Large EAEs (1.23) were found at the sites in eastern China, and the FMFs also were large (0.89) at those sites. This result can be attributed to the strong impacts of anthropogenic in the more urbanized eastern part of the country. On the other hand, large EAE values also occurred at the clean sites in northeastern China, including Mt. Longfeng (1.38), where the sphericity fraction was 58.5 and the FMF 0.90 . This shows that small particles can have stronger effects in these areas relative to some other regions of China. The EAE at Lin' an was larger than that at Shangdianzi in the North China Plain or Mt. Longfeng in Northeastern China for most months according to data from Che et al. (2009c). At the urban sites, large EAEs were found at sites in southern China, including Nanning (EAE $=1.36$, sphericity fraction $=70.12, \mathrm{FMF}=0.95)$, Panyu $(\mathrm{EAE}=1.43$, sphericity fraction $=75.55, \mathrm{FMF}=0.93)$ and Zhuzilin $(\mathrm{EAE}=1.45$, sphericity fraction $=55.51, \mathrm{FMF}=0.94)$. This is likely because the large populations and widespread vehicle ownership in those cities led to the dominance of fine-mode particles throughout the year. Cheng et al. (2015) found a unimodal distribution of EAE centred in 1.1-1.6 with the occurrence frequency about $72 \%$, which indicated an abundance of fine primary particles at Shanghai in eastern China. At the urban Nanjing site, which is in eastern central China, small particles were dominant, and the annual average EAE was $1.21 \pm 0.28$ (Li et al., 2015).

\subsection{Spatial distribution of aerosol single-scattering albedo}

The spatial distribution of SSA at $440 \mathrm{~nm}$ of the 50 CARSNET stations is shown in Fig. 4. As a frame of reference, Eck et al. (2005) reported that that $\mathrm{SSA}_{440 \mathrm{~nm}}$ from the AERONET retrievals were 0.82 to 0.98 globally. We note that $\mathrm{SSA}_{440 \mathrm{~nm}}$ values in this range reflect slightly to strongly absorbing aerosols, and these particles originate from multitude sources (Che et al., 2018). The SSA $440 \mathrm{~nm}$ values decreased from remote and rural to the urban sites and from west to east, which means that there were higher percentages of absorbing particles at the urban and eastern stations. The average $\mathrm{SSA}_{440 \mathrm{~nm}}$ at the remote sites was about 0.91 , which is indicative of particles with moderate absorption. The absorbing aerosols at the remote sites were more likely mineral dust particles because those sites are less likely to be affected by carbonaceous particles, which also are absorbing but mainly produced by anthropogenic activities. The $\mathrm{SSA}_{440 \mathrm{~nm}}$ values for the arid and semi-arid sites were 0.89 . The relatively high SSA at Tazhong (0.92) was prob- ably due to slightly absorbing, coarse mode dust particles $(\mathrm{EAE}=0.25)$.

A study by Bi et al. (2011) showed that SSAs increased slightly with wavelength when dust was present at the SACOL site. Moderately absorbing particles were found in our study on or near the Chinese Loess Plateau where the $\mathrm{SSA}_{440 \mathrm{~nm}}$ values were typically 0.88 to 0.89 . Eck et al. (2005) concluded that the spectral SSA demonstrated effects of dust at Yulin because the SSA increased for wavelengths from 440 to $675 \mathrm{~nm}$. At the rural sites in eastern China, large $\mathrm{SSA}_{440 \mathrm{~nm}}$ values mainly occurred at sites in the YRD affected anthropogenic influences; these include Tonglu (0.93), Xiaoshan (0.93), Xiyong (0.94). Che et al. (2018) found the slightly absorbing particles came from industrial activity and anthropogenic sources at YRD region with the $\mathrm{SSA}_{440 \mathrm{~nm}}$ between 0.91 and 0.94 .

The average value of $\mathrm{SSA}_{440 \mathrm{~nm}}$ at the urban sites was 0.90 , which indicates that particles with moderate absorption dominated the aerosol populations. Cheng et al. (2015) reported a seasonal range of SSA from 0.88 to 0.91 at Shanghai, with higher values in autumn and winter compared with spring and summer. Lower $\mathrm{SSA}_{440 \mathrm{~nm}}$ values occurred at the urban sites and industrial regions in northeastern China, such as Shenyang (0.84), Anshan (0.89), Fuhsun (0.84), which indicates that the particles were more strongly absorbing in that region. On the other hand, higher $\mathrm{SSA}_{440 \mathrm{~nm}}$ values were found at urban sites in southern China, including Nanning (0.92), Panyu (0.90) and Zhuzilin (0.96), and this indicates that the particles at those sites were slightly or weakly absorbing.

Moreover, we found that the $\mathrm{SSA}_{440 \mathrm{~nm}}$ spatial distribution reflected the percentages of absorbing aerosols at the urban sites both in northern and eastern China. The reports of Dubovik and King (2000), Dubovik et al. (2002, 2006) showed that SSA values vary with both particle size and composition, and Su et al. (2017) used the variations in SSA with wavelength to indicate the presence of brown carbon aerosols at Tianjin, a coastal megacity in China. Qin et al. (2017) suggested that the small SSAs found at Shijiazhuang indicated the presence of fine-mode absorbing particles, such as brown carbon. Zhuang et al. (2014) reported that the SSA at the Nanjing urban site ranged from 0.90 to 0.95 , and the aerosol was more absorbing in autumn, possibly due to the biomass burning emission in the YRD. As evident in the results presented in Sect. 3.1, one can see that the $R_{\text {effT }}, R_{\text {effF }}$ and $R_{\text {effC }}$ between northeastern and southern China was very similar. For example, at Shenyang, a megacity in northeastern China, the effective radii of total, fine- and coarse-mode particles were $0.31,0.16,2.23 \mu \mathrm{m}$ and the corresponding volumes were $0.22,0.12,0.10 \mu \mathrm{m}^{3}$ per $\mu \mathrm{m}^{2}$, respectively. At Hangzhou in the YRD region, the $R_{\text {effT }}, R_{\text {effF }}$ and $R_{\text {effC }}$ were $0.30,0.17$, and $2.21 \mu \mathrm{m}$ with volumes of about $0.22,0.12$, and $0.10 \mu \mathrm{m}^{3}$ per $\mu \mathrm{m}^{2}$, respectively. Therefore, the different $\mathrm{SSA}_{440 \mathrm{~nm}}$ distributions in the two regions may be attributed to the special aerosol composition related to the urban in- 


\section{FMF distribution in China}

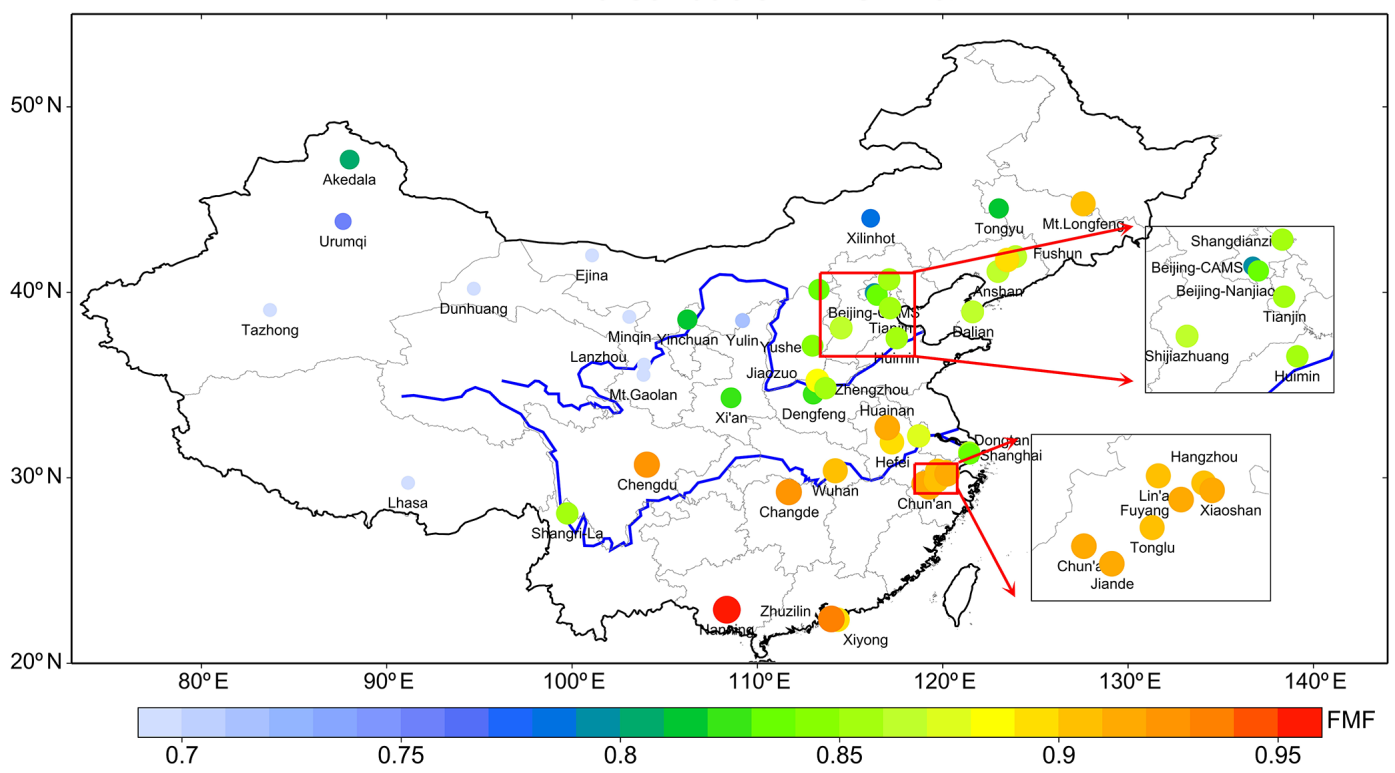

Figure 4. Annual spatial distribution of fine-mode fraction at the CARSNET sites.

dustrial background of northeastern China (lower SSA440 nm) and more anthropogenic sources in eastern China (higher $\mathrm{SSA}_{440 \mathrm{~nm}}$ ).

Dust aerosols with light-absorbing properties occur more frequently in spring in northeastern China than in more southern regions (Zhao et al., 2018). Anthropogenic emissions from seasonal biomass burning and residential heating are two other main factors that affect aerosol composition between the two regions (Che et al., 2018). There was high percentage of absorbing aerosols at the northeastern sites, especially in winter, more than likely caused by emissions of carbonaceous aerosol from residential heating (Zhao et al., 2015). Climatic conditions are also the main factors affecting the absorption characteristics of aerosols in different regions of northern and southern China. The increased light scattering could well be due to the particles hygroscopic growth demonstrated in other studies. For example, Mai et al. (2018) found that AODs and SSAs both increased with relative humidity at Guangdong in the Pearl River Delta (PRD) region, which suggests that condensational growth can affect aerosol optical properties.

\subsection{Spatial distributions of absorption aerosol optical depth (AAOD)}

The spatial distribution of AAOD at $440 \mathrm{~nm}$, shown in Fig. 5, indicates that, overall, the $\mathrm{AAOD}_{440 \mathrm{~nm}}$ values increased from north to south and from remote and rural to urban sites. Lower AAOD $440 \mathrm{~nm}$ values were found at the remote stations, where the average value was 0.01 . The AAOD $440 \mathrm{~nm}$ at Akedala, a remote site in northwestern China, was 0.02, and that was higher than at Shangri-La or Lhasa (0.01), both of which are on the Tibetan Plateau. The low AAOD $440 \mathrm{~nm}$ values throughout that region indicate that the aerosol population was not strongly absorbing. Compared with these three sites, the average $\mathrm{AAOD}_{440 \mathrm{~nm}}$ values at the arid and semiarid sites were higher (0.03); for example, an $\mathrm{AAOD}_{440 \mathrm{~nm}}$ of 0.05 was found at Tazhong, which is adjacent to the desert, and that indicates that the aerosol particles were more absorbing. As discussed in Sect. 3.2 and 3.3, dust aerosols likely make a significant contribution to aerosol light absorption in the areas impacted by the desert areas.

The low AAOD $440 \mathrm{~nm}$ found at Xilinhot (0.02) was probably due to the low aerosol loadings $\left(\mathrm{AOD}_{440 \mathrm{~nm}}=0.21\right)$ in this region. The $\mathrm{AAOD}_{440 \mathrm{~nm}}$ values at the Mt. Gaolan and Yulin rural sites, which are on or around the CLP, were about 0.04 and 0.03 , respectively, and the particles were moderately absorbing $(\mathrm{SSA}=0.89)$. The large $\mathrm{AAOD}_{440 \mathrm{~nm}}$ at $\mathrm{Da}-$ tong (0.09) can be explained by the high $\mathrm{AOD}_{440 \mathrm{~nm}}(0.58)$ there. Indeed, large $\mathrm{AAOD}_{440 \mathrm{~nm}}$ values were found at rural sites in eastern China, where there were high AODs and low SSAs, as noted in Sect. 3.2 and 3.3. Of these sites, Dengfeng $\left(\mathrm{AOD}_{440 \mathrm{~nm}}=0.08\right)$ and Huimin $\left(\mathrm{AOD}_{440 \mathrm{~nm}}=\right.$ 0.08) are located on the North China Plain, while Huainan $\left(\mathrm{AOD}_{440 \mathrm{~nm}}=0.10\right)$ is on the Guanzhong Plain. Lower $\mathrm{AAOD}_{440 \mathrm{~nm}}$ values, from 0.02 to 0.03 , occurred at Tongyu (0.03), which is in a semi-arid region in northeastern China, at the Mt. Longfeng (0.03) regional background site on the Northeast China Plain, at the Yushe rural site in northern China (0.03), and at the clean Xiyong site in the PRD (0.02).

Several urban sites showed $\mathrm{AAOD}_{440 \mathrm{~nm}}$ values greater than 0.10: these include Fushun (0.11) and Shenyang $(0.14)$ in northeastern China, Lanzhou (0.10) in northwestern China, and Nanjing (0.10) and Wuhan (0.11) in east- 


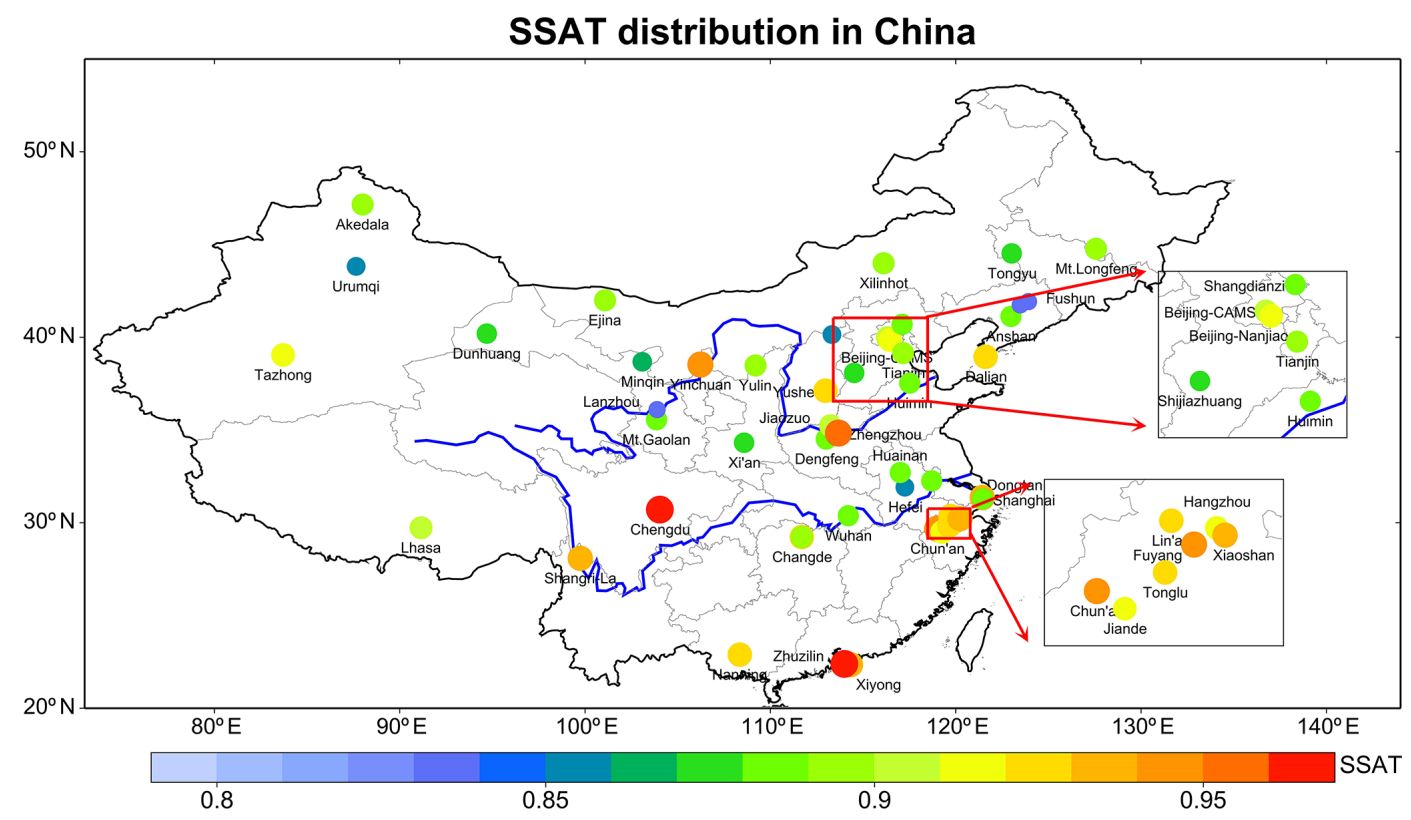

Figure 5. Annual spatial distribution of the single-scattering albedo (SSA) at $440 \mathrm{~nm}$ at the CARSNET sites.

ern and central China. Lower $\mathrm{AAOD}_{440 \mathrm{~nm}}$ values occurred in other urban areas, such as Yinchuan $\left(\mathrm{AAOD}_{440 \mathrm{~nm}}=\right.$ $\left.0.02, \mathrm{AOD}_{440 \mathrm{~nm}}=0.37\right)$ in the northwest and Zhuzilin $\left(\mathrm{AAOD}_{440 \mathrm{~nm}}=0.03, \mathrm{AOD}_{440 \mathrm{~nm}}=0.66\right)$ in the PRD; both of these sites had relatively low $\mathrm{AOD}_{440}$ values, indicating weaker anthropogenic influences compared with metropoli$\tan$ regions in some other areas. We note that there are significant uncertainties in relating aerosol absorbing properties to particle types, such as black carbon, organic matter, and mineral dust (Russell et al., 2010; Giles et al., 2012). Nonetheless, the information presented here on the spatial distribution of AAODs over China may be useful for further investigations into the relationships between light absorption and particle type (Liu et al., 2018; Schuster et al., 2016a, b).

\subsection{Spatial distribution of direct aerosol radiative effect at the Earth's surface and top of the atmosphere}

The spatial distributions of the DAREs calculated for both the bottom and top of the atmosphere are shown in Fig. 6 . Overall, the DARE-BOAs increased from northwest to southeast and from rural to urban sites, consistent with impacts from the densely populated regions around the sites. The average DARE-BOA at the remote sites was $-24.40 \mathrm{~W} \mathrm{~m}^{-2}$, and, in comparison, a higher DARE-BOA $\left(-33.65 \mathrm{~W} \mathrm{~m}^{-2}\right)$ occurred at Akedala, which occurred in a remote region of northwestern China. The $\mathrm{AOD}_{440 \mathrm{~nm}}$ at Akedala was relatively low (0.17) and the SSA moderate (0.90). The moderate absorption of aerosol could lead to more strong surface cooling effects with little higher DAREBOA than the other remote sites. The DARE-BOAs for Lhasa and Shangri-La were -22.13 and $-17.43 \mathrm{~W} \mathrm{~m}^{-2}$, re- spectively. These results indicate weaker surface cooling effects at the remote sites relative to other regions because the aerosol loadings were relatively low, as indicated by $\mathrm{AOD}_{440 \mathrm{~nm}}$ values of $<0.20$.

The average DARE-BOTs at the arid and semi-arid sites in China were about $-56.43 \mathrm{~W} \mathrm{~m}^{-2}$, and those high DARE-BOAs can be explained by the moderately absorbing particles $(\mathrm{SSA}=0.89)$ and large $\mathrm{AOD}_{440 \mathrm{~nm}}$ values (0.32) compared with the remote sites. A large DARE-BOA $\left(-91.20 \mathrm{~W} \mathrm{~m}^{-2}\right)$ occurred at the Tazhong site near the northwestern deserts, and there the high AOD (0.60) and the slight absorption of mineral dust (SSA $=0.92)$ imply substantial surface cooling. The average DARE-BOA for rural sites on the Chinese Loess Plateau or surrounding area was $-74.67 \mathrm{~W} \mathrm{~m}^{-2}$, which also implies cooling at the surface.

Several rural sites in northern and eastern China had large DARE-BOA values; these include Huimin $\left(-111.58 \mathrm{~W} \mathrm{~m}^{-2}\right), \quad$ Dengfeng $\left(-104.78 \mathrm{~W} \mathrm{~m}^{-2}\right), \quad$ and Huainan $\left(-129.17 \mathrm{~W} \mathrm{~m}^{-2}\right)$, and at those sites the AODs were high, from 0.80 to 0.90 , and the SSAs were $\sim 0.89$. These results show stronger surface cooling effects at sites influenced by anthropogenic emissions compared with the remote sites or those near the deserts. The large negative DARE-BOA values $\left(-103.28 \mathrm{~W} \mathrm{~m}^{-2}\right)$ at the urban sites indicate that the combination of high $\mathrm{AOD}_{440 \mathrm{~nm}}$ values (0.79) and moderate SSAs (0.90) can cause significant surface cooling. Indeed, anthropogenic emissions presumably led to the high DARE-BOAs at urban sites, including Shenyang $\left(-144.88 \mathrm{~W} \mathrm{~m}^{-2}\right)$ and Fushun $\left(-116.91 \mathrm{~W} \mathrm{~m}^{-2}\right)$ on the Northeast China Plain, Xi' an on the Guanzhong Plain $\left(-132.55 \mathrm{~W} \mathrm{~m}^{-2}\right)$, Chengdu in the Sichuan Basin $\left(-110.42 \mathrm{~W} \mathrm{~m}^{-2}\right)$, Lanzhou in the western 


\section{AAOD distribution in China}

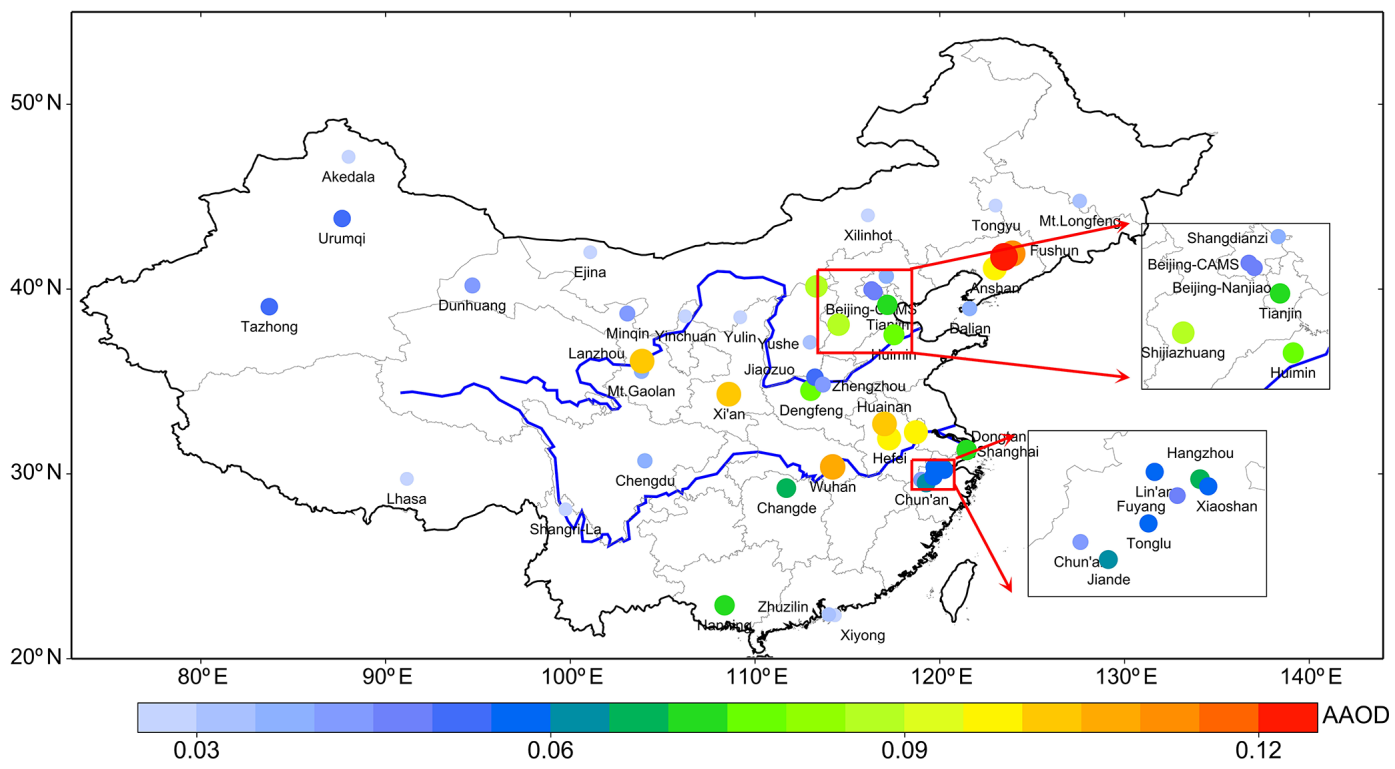

Figure 6. Annual spatial distribution of absorption aerosol optical depth (AAOD) at $440 \mathrm{~nm}$ at the CARSNET sites.

region $\left(-126.17 \mathrm{~W} \mathrm{~m}^{-2}\right)$, and Nanjing $\left(-143.38 \mathrm{~W} \mathrm{~m}^{-2}\right)$ and Wuhan $\left(-171.80 \mathrm{~W} \mathrm{~m}^{-2}\right)$ in central China. These results indicate that anthropogenic aerosols can cause significant direct radiative effects at urban sites.

The DARE-TOAs increased from north to south and from rural to urban sites, and the average DARE-TOA for the remote stations was low, about $-4.79 \mathrm{~W} \mathrm{~m}^{-2}$ (Fig. 7). The DARE-TOAs at Lhasa and Shangri-La were -5.04 and $-8.93 \mathrm{~W} \mathrm{~m}^{-2}$, respectively. A notably small DARE-TOA was found at Akedala $\left(-0.42 \mathrm{~W} \mathrm{~m}^{-2}\right)$, indicating that the effects of the aerosol on the temperature of Earth-atmosphere system there would be weak. The average DARE-TOA at the arid and semi-arid sites was $-10.17 \mathrm{~W} \mathrm{~m}^{-2}$. The large DARE-TOA found at Tazhong $\left(-23.49 \mathrm{~W} \mathrm{~m}^{-2}\right)$ could represent the larger contribution of slightly absorbing mineral aerosols $(\mathrm{SSA}=0.92)$ and a large AOD $(0.60)$; this indicates more cooling at the surface through the absorption and scattering solar radiation compared with the less impacted sites. This is consistent with the results for Tazhong discussed in Sect. 3.1, which showed high volumes of coarse-mode particles with large radii.

The average DARE-TOA at rural sites on the Chinese Loess Plateau or nearby was about $-14.56 \mathrm{~W} \mathrm{~m}^{-2}$. Although the $\mathrm{SSA}_{440 \mathrm{~nm}}$ were close between Mt. Gaolan and Yulin, about 0.89, the TOAs were quite different (Mt. Gaolan $-20.87 \mathrm{~W} \mathrm{~m}^{-2}$; Yulin $-9.09 \mathrm{~W} \mathrm{~m}^{-2}$ ), which could be due to the different $\mathrm{AOD}_{440 \mathrm{~nm}}$, about 0.36 and 0.32 , respectively. In rural eastern China, the DARE-TOA was about $-32.40 \mathrm{~W} \mathrm{~m}^{-2}$, and, to put this in context, Che et al. (2018) found DARE-TOAs of $-40 \mathrm{~W} \mathrm{~m}^{-2}$ at rural sites in the YRD region, which is indicative of a relatively strong cooling effect. Low DARE-TOAs were found at the Mt.
Longfeng rural site in northeastern China (DARE-TOA = $\left.-11.34, \mathrm{AOD}_{440 \mathrm{~nm}}=0.34, \mathrm{SSA}=0.89\right)$ and at the Tongyu semi-arid site in northeastern China (DARE-TOA $=-8.87$, $\mathrm{AOD}_{440 \mathrm{~nm}}=0.23, \mathrm{SSA}=0.88$ ), where the aerosol loadings were relatively low and the absorption was moderate.

At the urban sites at central and eastern China, the average DARE-TOA values were about $-30.05 \mathrm{~W} \mathrm{~m}^{-2}$. Higher DARE-TOAs occurred at Anshan on the Northeast China Plain $\left(-39.66 \mathrm{~W} \mathrm{~m}^{-2}\right)$, Chengdu in the Sichuan Basin $\left(-52.21 \mathrm{~W} \mathrm{~m}^{-2}\right)$, Hangzhou in the YRD $\left(-40.16 \mathrm{~W} \mathrm{~m}^{-2}\right)$, Jiaozuo $\left(-39.35 \mathrm{~W} \mathrm{~m}^{-2}\right)$ and Zhengzhou $\left(-46.18 \mathrm{~W} \mathrm{~m}^{-2}\right)$ on the North China Plain, and Zhuzilin $\left(-40.15 \mathrm{~W} \mathrm{~m}^{-2}\right)$ in the PRD region. The high DARE-TOA values at these urban sites imply relatively strong cooling effects due to higher aerosol loadings in the atmosphere.

\subsection{Spatial distributions of aerosol mixing properties}

The spatial distribution of aerosol mixing properties (Fig. 8) was obtained by using the $\mathrm{SSA}_{440 \mathrm{~nm}}$, FMF, and EAE results to classify the particles based on size and absorbing properties. In previous studies by Zheng et al. (2017) and Che et al. (2018), the particles in this study were grouped into eight types as shown in Table 2. Moreover, the FMF has been provided to give the particle size information in the group of the particles.

At the remote Akedala and Lhasa sites $(\mathrm{FMF}=0.70-0.78$ and $\mathrm{SSA}_{440 \mathrm{~nm}}=0.85$ ), the percentages of mixed absorbing particles (Type V) were 35\%-40\%, while at Shangri-la $\left(\mathrm{FMF}=0.76, \mathrm{SSA}_{440 \mathrm{~nm}}=0.84\right)$ the percentage was slightly lower, $24.62 \%$. The characteristics of the particles at these remote, high-altitude sites were probably affected by the 


\section{BOA distribution in China}

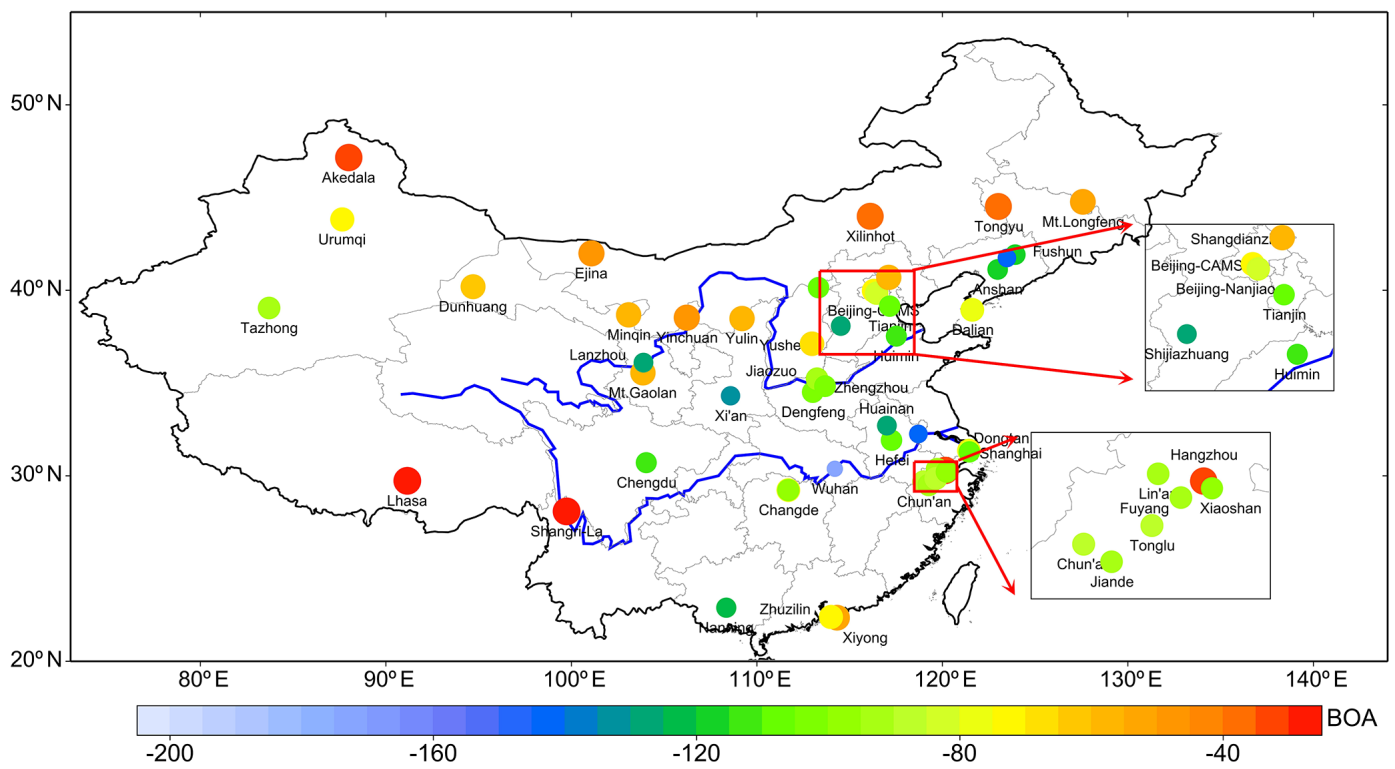

Figure 7. Annual spatial distribution of direct aerosol radiative effect at the bottom of the atmosphere at the CARSNET sites.

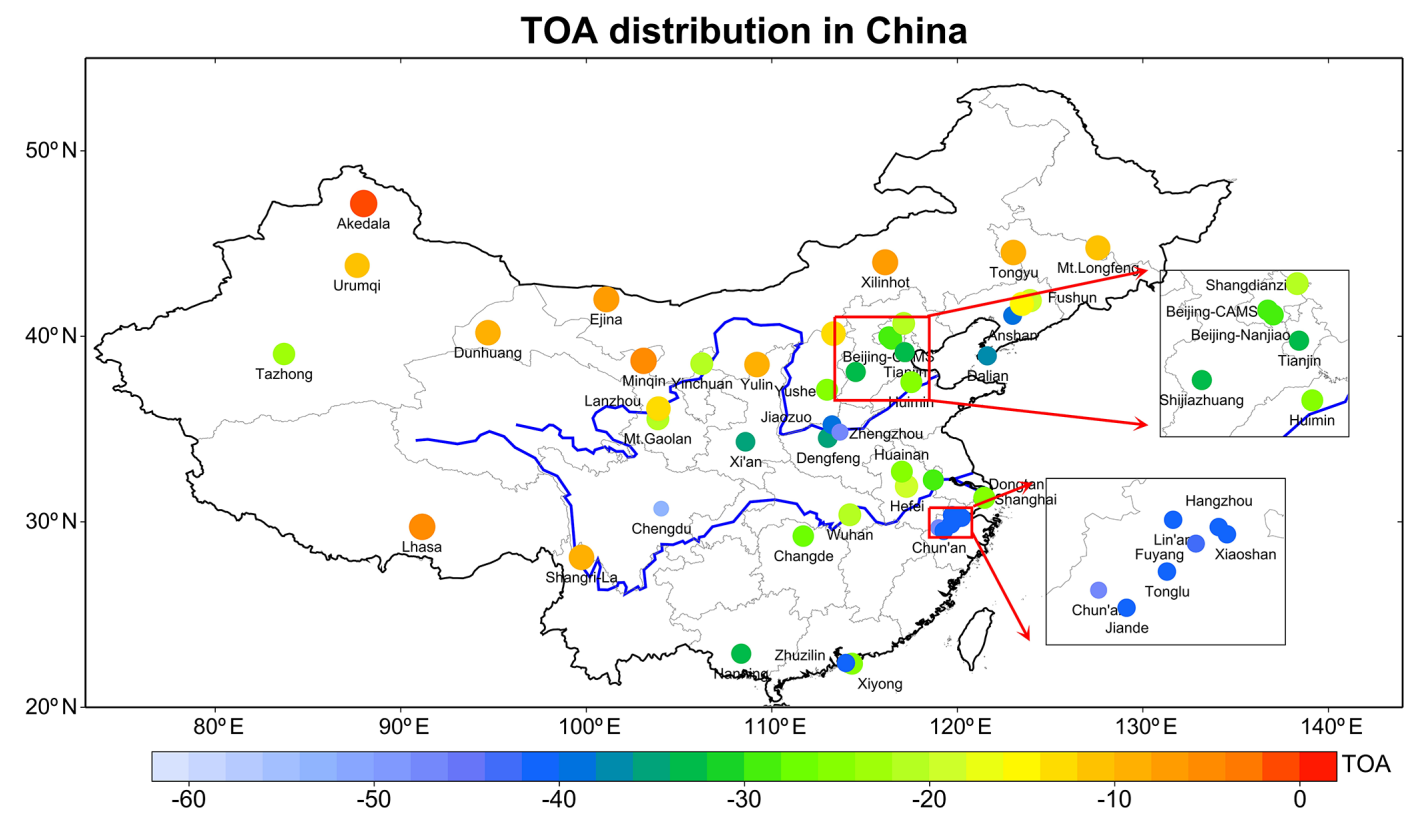

Figure 8. Annual spatial distribution of direct aerosol radiative effect at the top of the atmosphere at the CARSNET sites.

rugged topography, which would promote particle mixing. The proportion of coarse-mode particles (mainly dust)with moderate to strong absorption (Group VII) was highest at the arid and semi-arid sites. The percent abundances of Group VII particles were $57.90 \%$ at Dunhuang $(\mathrm{AE}=0.26$, $\left.\mathrm{SSA}_{440 \mathrm{~nm}}=0.85, \mathrm{FMF}=0.43\right)$ and $58.52 \%$ at Tazhong $\left(\mathrm{AE}=0.20, \mathrm{SSA}_{440 \mathrm{~nm}}=0.87, \mathrm{FMF}=0.37\right)$, respectively. Mixed absorbing particles (Type V) and strongly absorbing dust particles (Group VII) accounted for $30 \%$ to $70 \%$ of the aerosol in the rural sites on or near the CLP. The percentages of mixed absorbing particles (Type V) at Mt. Gaolan, Yulin, and Datong were $31.98 \%, 45.22 \%$, and $29.04 \%$, respectively, and the average FMFs at those sites ranged from 0.70 to 0.76 .

The proportions of the coarse-mode aerosols with strongly absorbing properties in Group VII was about $35.23 \%$ at Mt. Gaolan and $21.21 \%$ at Yulin, which was mainly dust particles, with the FMFs at those sites being 0.43 and 0.48 , 


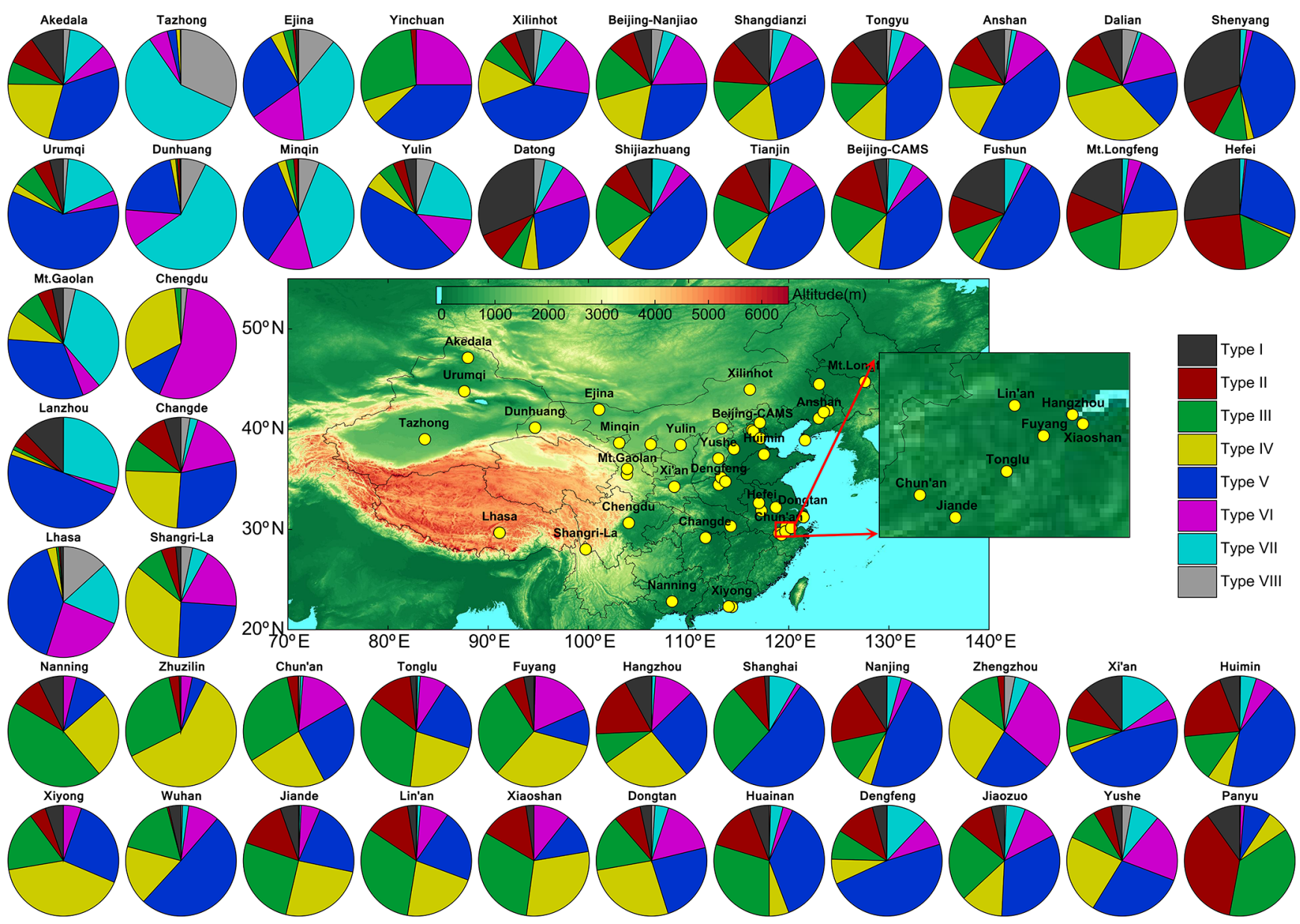

Figure 9. Annual spatial distribution of the aerosol type classification of types I-VII at the CARSNET sites.

respectively. The proportion of coarse-mode particles with strongly absorbing properties in Group VII and coarse-mode particles with weakly absorbing properties in Group VIII at the rural sites in eastern China was $<11 \%$. These patterns indicated that there are differences between the eastern region and northwestern China because in the east coarse-mode particles only make a minor contribution to aerosol absorption. The percentage of fine-mode particles with weakly absorbing properties in Type IV and mixed absorbing particles in Type $\mathrm{V}$ combined to be about $\sim 50 \%$ at the eastern sites. This result suggests that mixed aerosols originated from a variety of sources and that many of the sites were affected by anthropogenic emissions from megacities upwind.

The fine-mode particles with absorbing properties in Types I, II, III, and V at most of the urban sites accounted for $50 \%$ to $90 \%$. The percentages of these four particle types combined were especially large in eastern China; for example, at Panyu, particle Types I-IV composed $90.83 \%$ of the total and the FMF there was $0.90-0.94$, while at Zhuzilin, the percentage of Types I-IV was $92.55 \%$ and the FMF was 0.92-0.94. These results are another indication that fine-mode particles are important for light absorption in ur- ban areas. In contrast, the Lanzhou and Ürümqi urban sites were less affected by absorbing fine particles because the percentages of Type I-IV particles were only $19.73 \%$ and $18.36 \%$, respectively. The mixed absorbing Type V particles accounted for large percentages of the total at Lanzhou $(48.80 \%, \mathrm{EAE}=0.88, \mathrm{SSA}=0.82, \mathrm{FMF}=0.73)$ and at Ürümqi $(59.39 \%, \mathrm{EAE}=0.94, \mathrm{SSA}=0.84, \mathrm{FMF}=0.75)$. Different from the other urban sites, these patterns show that larger particles had significant contributions to the aerosol absorption at these two northwestern sites.

\section{Conclusions}

Aerosol microphysical and its optical properties obtained from the ground-based sun photometer deployed at 50 CARSNET stations were used to begin the development of their climatology characteristics and to investigate potential aerosol-climate effects over vast area of China. Direct aerosol radiative effects (DAREs) at the bottom and at the top of the atmosphere were calculated, and eight types of aerosols were classified based on the particle size and ab- 
sorbing properties. The annual mean values of the $R_{\text {effT }}$ decreased from the arid and semi-arid sites $(0.55 \mu \mathrm{m})$ to the urban sites $(0.37 \mu \mathrm{m})$. The aerosol volumes increased from the remote sites $\left(0.05 \mu \mathrm{m}^{3}\right.$ per $\left.\mu \mathrm{m}^{2}\right)$ to the urban sites $\left(0.21 \mu \mathrm{m}^{3}\right.$ per $\left.\mu \mathrm{m}^{2}\right)$. The volumes of coarse-mode particles were larger than those for the fine mode at the remote and arid and semiarid sites - this can be explained by the greater relative abundances of mineral dust compared with pollution-derived particles at those sites. At the urban sites, where anthropogenic influences were relatively strong, the proportion of fine-mode particles increased gradually with aerosol volume.

The $\mathrm{AOD}_{440 \mathrm{~nm}}$ progressively increased from the remote sites (0.12), to the arid and semi-arid sites (0.32), to rural sites in eastern China (0.70), and finally to the urban sites (0.79), which were the ones most strongly affected by anthropogenic activities. The average EAE $_{440-870 \mathrm{~nm}}$ values at the arid and semi-arid sites were relatively low (0.71), which indicates an important contribution of larger particles to the aerosol extinction in those regions. The consistently large EAE $_{440-870 \mathrm{~nm}}$ values at the urban sites $(>1.20)$ and the high FMFs that those sites $(0.88)$ are evidence that fine-mode particles are prevalent throughout year. The average $\mathrm{SSA}_{440 \mathrm{~nm}}$ values at the remote, rural, and urban sites were relatively similar, averaging about 0.89 , and this indicates the particles were moderately absorbing.

Overall, dust aerosols with light-absorbing properties (in spring) and emissions from biomass burning and residential heating during the colder months were the main factors that led to spatial differences in the percentages of absorbing aerosols over China. The $\mathrm{AAOD}_{440 \mathrm{~nm}}$ values increased from the remote sites (0.01), to the arid and semi-arid sites (0.03), to the rural sites of eastern China (0.05), and finally to the urban sites (0.07). High $\mathrm{AAOD}_{440 \mathrm{~nm}}$ values were caused by light-absorbing dust aerosols at the rural sites and by the strong anthropogenic emissions in the metropolitan areas. The spatial patterns in the absorbing aerosols were not only affected by the chemical composition of the aerosol but also by physical effects imposed by topography, weather, and climate.
The average DARE-BOA values were $-24.40 \mathrm{~W} \mathrm{~m}^{-2}$ at the remote sites, $-56.43 \mathrm{~W} \mathrm{~m}^{-2}$ at the arid and semi-arid sites, $-74.67 \mathrm{~W} \mathrm{~m}^{-2}$ at the sites on the CLP or nearby, $-85.25 \mathrm{~W} \mathrm{~m}^{-2}$ at the rural sites in eastern China, and $-103.28 \mathrm{~W} \mathrm{~m}^{-2}$ at the urban sites. The larger DARE-BOA values at the urban sites imply stronger cooling effects from anthropogenic emissions compared with those from mineral dust at the remote sites or those near the desert. Moreover, larger DARE-TOAs also occurred at the urban sites $\left(-30.05 \mathrm{~W} \mathrm{~m}^{-2}\right)$, which indicates strong cooling effects due to the large aerosol extinctions between the Earthatmosphere system displayed by the moderate to strong light absorption. Mixed-absorbing particles were the most abundant aerosol type in the remote and rural sites on or near the Chinese Loess Plateau and in eastern China. Mineral dust particles with moderate to strong absorbing properties were dominant at the arid and semi-arid sites, while absorbing fine-mode particles accounted for $50 \%$ to $90 \%$ of the aerosol at most urban sites.

The results of this study have considerable value for ground-truthing satellite observations and for validating aerosol models. Moreover, the results have also provided significant information on aerosol optical and radiative properties for different types of sites covering a broad expanse of China. These results also are a major step towards developing climatology for aerosol microphysical and optical properties for China and even East Asia.

Data availability. The detailed data used in the study have been deposited in the figshare database (Che et al., 2019b, https://doi.org/10.6084/m9.figshare.9731339.v2). 


\section{Appendix A}

Table A1. Site information for the 50 CARSNET sites used in this study.

\begin{tabular}{|c|c|c|c|c|c|c|c|}
\hline No. & Site name & Longitude & Latitude & Altitude & Site information & Obs. Num & Period \\
\hline \multicolumn{8}{|c|}{ Remote sites (three sites) } \\
\hline 1 & Akedala & 47.12 & 87.97 & 562.0 & $\begin{array}{l}55 \mathrm{~km} \text { west of Fuhai county, Xinjiang Province, } \\
\text { and } 250-300 \mathrm{~km} \text { southeast of Kazakhstan }\end{array}$ & 947 & 2010-2017 \\
\hline 2 & Lhasa & 29.67 & 91.13 & 3663.0 & In the centre of Lhasa, Qinghai-Tibetan Plateau. & 437 & 2012-2017 \\
\hline 3 & Shangri-La & 28.02 & 99.73 & 3583.0 & $\begin{array}{l}12 \mathrm{~km} \text { northeast of Shangri-La county, Diqing area, } \\
\text { Yunnan Province }\end{array}$ & 325 & 2013-2017 \\
\hline \multicolumn{8}{|c|}{ Arid and semi-arid sites (six sites) } \\
\hline 4 & Dunhuang & 40.15 & 94.68 & 1139.0 & $\begin{array}{l}1.5 \mathrm{~km} \text { northeast of Dunhuang, Gansu Province, } \\
\text { near the Kumtag Desert in China }\end{array}$ & 2030 & 2012-2017 \\
\hline 5 & Ejina & 41.95 & 101.07 & 940.5 & $\begin{array}{l}\text { West of Inner Mongolia, near Mongolia, } \\
\text { and Badanjilin Desert }\end{array}$ & 1970 & 2013-2017 \\
\hline 6 & Minqin & 38.63 & 103.08 & 1367.0 & $\begin{array}{l}\text { In Minqin county, east of the Tenggeli desert and } \\
\text { north of the Badanjilin Desert, Gansu Province }\end{array}$ & 481 & 2013-2017 \\
\hline 7 & Tazhong & 39.00 & 83.67 & 1099.4 & $\begin{array}{l}\text { In the middle of Taklamakan Desert, } \\
\text { Xinjiang Province }\end{array}$ & 1279 & 2013-2017 \\
\hline 8 & Xilinhot & 43.95 & 116.12 & 1003.0 & $\begin{array}{l}5 \mathrm{~km} \text { southeast of Xilinhot, near Hunshandake, } \\
\text { Inner Mongolia Province, }\end{array}$ & 1464 & 2013-2017 \\
\hline 9 & Tongyu & 44.42 & 122.87 & 151.0 & In Tonyu, west of Jilin Province & 817 & 2010-2011 \\
\hline
\end{tabular}

Rural sites on (or near) the Chinese Loess Plateau (three sites)

\begin{tabular}{llllllll}
\hline 10 & Mt. Gaolan & 36.00 & 103.85 & 2161.6 & $5 \mathrm{~km}$ north of Lanzhou in Gansu Province & 769 & $2015-2016$ \\
11 & Yulin & 38.43 & 109.20 & 1135.0 & $10 \mathrm{~km}$ north of Yulin in Shaanxi Province & 716 & $2010-2016$ \\
12 & Datong & 40.10 & 113.33 & 1067.3 & $\begin{array}{l}\text { Within 9 km of Datong but within an area of rapid } \\
\text { urbanization, Shanxi Province }\end{array}$ & 914 & $2014-2017$ \\
& & & & &
\end{tabular}

\begin{tabular}{|c|c|c|c|c|c|c|c|}
\hline \multicolumn{8}{|c|}{ Rural sites in eastern China (15 sites) } \\
\hline 13 & Changde & 29.17 & 111.70 & 565.0 & $18 \mathrm{~km}$ northwest of Changde, Hunan Province & 344 & 2013-2016 \\
\hline 14 & Dongtan & 31.52 & 121.96 & 10.0 & On Chongmin Island, 30km east of Shanghai & 986 & 2012-2016 \\
\hline 15 & Chun'an & 29.61 & 119.05 & 171.4 & $151 \mathrm{~km}$ southwest of Hangzhou, Zhejiang Province & 1286 & 2011-2015 \\
\hline 16 & Huimin & 37.48 & 117.53 & 11.7 & $100 \mathrm{~km}$ northeast of Jinan, Shandong Province & 2243 & 2009-2017 \\
\hline 17 & Lin'an & 30.30 & 119.73 & 138.6 & $\begin{array}{l}150 \mathrm{~km} \text { northeast of Shanghai and } 50 \mathrm{~km} \text { west } \\
\text { of Hangzhou, Zhejiang Province }\end{array}$ & 1834 & 2011-2015 \\
\hline 18 & Mt.Longfeng & 44.73 & 127.60 & 330.5 & $\begin{array}{l}\text { In Wuchang county, } 175 \mathrm{~km} \text { northeast of Harbin, } \\
\text { Heilongjiang Province }\end{array}$ & 1515 & 2012-2016 \\
\hline 19 & Fuyang & 30.07 & 119.95 & 17.0 & $44.1 \mathrm{~km}$ southwest of Hangzhou, Zhejiang Province & 710 & 2014-2015 \\
\hline 20 & Shangdianzi & 40.65 & 117.12 & 293.0 & In Miyun county, $150 \mathrm{~km}$ northeast of Beijing & 1520 & 2014-2017 \\
\hline 21 & Yushe & 37.07 & 112.98 & 1041.5 & $1.5 \mathrm{~km}$ east of Yushe, Shanxi Province & 1479 & 2013-2017 \\
\hline 22 & Dengfeng & 34.46 & 113.02 & 350.0 & $75 \mathrm{~km}$ southwest of Zhengzhou, Henan Province & 712 & 2013 \\
\hline 23 & Huainan & 32.65 & 117.02 & 52.0 & Central Hefei, Anhui Province & 794 & 2014-2015 \\
\hline 24 & Jiande & 29.45 & 119.28 & 89.0 & Southwest of Hangzhou, Zhejiang Province & 1550 & 2011-2015 \\
\hline 25 & Tonglu & 29.80 & 119.64 & 46.1 & $100 \mathrm{~km}$ northwest of Hangzhou, Zhejiang Province & 1717 & 2011-2015 \\
\hline 26 & Xiaoshan & 30.16 & 120.25 & 14.0 & South of Hangzhou, Zhejiang Province & 600 & 2014-2015 \\
\hline 27 & Xiyong & 22.28 & 114.33 & 155.2 & East of Shenzhen, Guangdong Province & 189 & 2016 \\
\hline \multicolumn{8}{|c|}{ Urban sites (23 sites) } \\
\hline 28 & Anshan & 41.08 & 123.00 & 23.0 & In Anshan, central Liaoning Province & 193 & 2009-2013 \\
\hline 29 & Beijing-Nanjiao & 39.80 & 116.47 & 31.3 & In southeastern Beijing & 1732 & 2014-2017 \\
\hline 30 & Beijing-CAMS & 39.93 & 116.32 & 106.0 & $\begin{array}{l}\text { Chinese Academy of Meteorological Sciences, } \\
\text { Beijing }\end{array}$ & 1113 & 2012-2018 \\
\hline 31 & Chengdu & 30.65 & 104.03 & 496.0 & In Chengdu, Sichuan Province & 55 & 2014-2015 \\
\hline 32 & Dalian & 38.90 & 121.63 & 91.5 & Southeastern coastal city in Liaoning Province & 736 & 2012-2015 \\
\hline 33 & Fushun & 41.88 & 123.95 & 80.0 & In Fushun, central Liaoning Province & 231 & 2009-2013 \\
\hline 34 & Hangzhou & 30.23 & 120.17 & 42.0 & In Hangzhou, Zhengjiang Province & 1663 & 2011-2015 \\
\hline 35 & Hefei & 31.98 & 116.38 & 92.0 & In Hefei, Anhui Province & 197 & 2016 \\
\hline 36 & Jiaozuo & 35.18 & 113.25 & 113.0 & Central Jiaozuo, Henan Province & 981 & 2016-2017 \\
\hline 37 & Lanzhou & 36.05 & 103.88 & 1517.3 & In Lanzhou, Gansu Province & 1493 & 2013-2017 \\
\hline 38 & Nanjing & 32.05 & 118.77 & 99.3 & In Nanjing, Jiangsu Province & 1258 & 2007-2015 \\
\hline 39 & Nanning & 22.82 & 108.35 & 172.0 & In Nanning, Guangxi Province & 286 & 2013-2017 \\
\hline 40 & Panyu & 23 & 113.35 & 145.0 & $\begin{array}{l}\text { In district of Guangzhou, } \\
\text { Guangdong Province }\end{array}$ & 436 & 2012-2016 \\
\hline
\end{tabular}


Table A1. Continued.

\begin{tabular}{|c|c|c|c|c|c|c|c|}
\hline No. & Site name & Longitude & Latitude & Altitude & Site information & Obs. Num & Period \\
\hline 41 & Shanghai & 31.22 & 121.55 & 14.0 & In the Pudong district of Shanghai & 144 & 2016 \\
\hline 42 & Shenyang & 41.77 & 123.50 & 60.0 & In Shenyang, central Liaoning Province & 541 & 2009-2013 \\
\hline 43 & Tianjin & 39.10 & 117.17 & 3.3 & Northern coastal city on the North China Plain & 1705 & $2013-2017$ \\
\hline 44 & Ürümqi & 43.78 & 87.62 & 935.0 & In Ürümqi, Xinjiang Province & 1411 & $2012-2017$ \\
\hline 45 & Xi'an & 34.43 & 108.97 & 363.0 & $\begin{array}{l}20 \mathrm{~km} \text { north of the centre of Xi' an but within the Jing River } \\
\text { industrial district, Shaanxi Province }\end{array}$ & 652 & $2012-2016$ \\
\hline 46 & Yinchuan & 38.48 & 106.22 & 1111.5 & In Yinchuan, Ningxia Province & 124 & 2017 \\
\hline 47 & Zhengzhou & 34.78 & 113.68 & 99.0 & In Zhengzhou, Henan Province & 1485 & $2013-2017$ \\
\hline 48 & Shijiazhuang & 38.03 & 114.53 & 75.0 & $\begin{array}{l}\text { Central Shijiazhuang, } \\
\text { Hebei Province }\end{array}$ & 1178 & $2015-2017$ \\
\hline 49 & Wuhan & 30.32 & 114.21 & 30 & $\begin{array}{l}\text { Central Wuhan, } \\
\text { Hubei Province }\end{array}$ & 220 & 2008 \\
\hline 50 & Zhuzilin & 22.32 & 114.00 & 63.0 & $\begin{array}{l}\text { Central Shenzhen, } \\
\text { Guangdong Province }\end{array}$ & 915 & 2010-2017 \\
\hline
\end{tabular}


Table A2. Annual data for aerosol microphysical properties and optical and direct radiative parameters.

\begin{tabular}{|c|c|c|c|c|c|c|c|c|c|c|c|c|c|c|c|c|}
\hline No. & Site & ${ }^{\mathrm{a}} \mathrm{ReffT}$ & ${ }^{\mathrm{a}} \mathrm{ReffF}$ & ${ }^{a} \operatorname{ReffC}$ & ${ }^{\mathrm{a}}$ VolT & ${ }^{\mathrm{a}} \mathrm{VolF}$ & ${ }^{\mathrm{a}} \mathrm{VolC}$ & ${ }^{\mathrm{a} A O D T}$ & ${ }^{b}$ EAE & ${ }^{\mathrm{a}} \mathrm{FMF}$ & ${ }^{\mathrm{a} S S A T}$ & ${ }^{\text {a Image }}$ & ${ }^{\mathrm{a}}$ Real & ${ }^{\mathrm{a}} \mathrm{AAOD}$ & ${ }^{\mathrm{a}} \mathrm{BOA}$ & ${ }^{\mathrm{a}} \mathrm{TOA}$ \\
\hline \multicolumn{17}{|c|}{ Remote sites (3 sites) } \\
\hline 1 & Akedala & 0.36 & 0.14 & 2.45 & 0.06 & 0.02 & 0.04 & 0.17 & 1.13 & 0.81 & 0.90 & 0.0117 & 1.4540 & 0.02 & -33.65 & -0.42 \\
\hline 2 & Lhasa & 0.64 & 0.13 & 2.26 & 0.05 & 0.01 & 0.04 & 0.10 & 0.77 & 0.66 & 0.90 & 0.0106 & 1.5541 & 0.01 & -22.13 & -5.04 \\
\hline \multirow[t]{2}{*}{3} & Shangri-La & 0.39 & 0.14 & 2.33 & 0.03 & 0.01 & 0.02 & 0.10 & 1.19 & 0.85 & 0.93 & 0.0086 & 1.4626 & 0.01 & -17.43 & -8.93 \\
\hline & Average & 0.47 & 0.14 & 2.35 & 0.05 & 0.01 & 0.03 & 0.12 & 1.03 & 0.77 & 0.91 & 0.0103 & 1.4902 & 0.01 & -24.40 & -4.79 \\
\hline \multicolumn{17}{|c|}{ Arid and semi-arid sites (6 sites) } \\
\hline 4 & Dunhuang & 0.62 & 0.14 & 1.52 & 0.15 & 0.02 & 0.13 & 0.33 & 0.48 & 0.44 & 0.88 & 0.0103 & 1.5491 & 0.04 & -63.61 & -8.96 \\
\hline 5 & Ejina & 0.56 & 0.14 & 1.78 & 0.11 & 0.02 & 0.09 & 0.24 & 0.64 & 0.52 & 0.89 & 0.0116 & 1.5265 & 0.03 & -47.66 & -7.20 \\
\hline 6 & Minqin & 0.56 & 0.13 & 1.87 & 0.13 & 0.02 & 0.11 & 0.30 & 0.68 & 0.59 & 0.86 & 0.0145 & 1.5430 & 0.04 & -59.83 & -5.01 \\
\hline 7 & Tazhong & 0.71 & 0.14 & 1.38 & 0.30 & 0.03 & 0.27 & 0.60 & 0.25 & 0.35 & 0.92 & 0.0054 & 1.5257 & 0.05 & -91.20 & -23.49 \\
\hline 8 & Xilinhot & 0.48 & 0.13 & 2.45 & 0.08 & 0.02 & 0.05 & 0.21 & 1.03 & 0.78 & 0.89 & 0.0139 & 1.5183 & 0.02 & -37.14 & -7.47 \\
\hline \multirow[t]{2}{*}{9} & Tongyu & 0.39 & 0.13 & 2.36 & 0.07 & 0.02 & 0.05 & 0.23 & 1.16 & 0.82 & 0.88 & 0.0179 & 1.5377 & 0.03 & -39.13 & -8.87 \\
\hline & Average & 0.55 & 0.14 & 1.89 & 0.14 & 0.02 & 0.12 & 0.32 & 0.71 & 0.58 & 0.89 & 0.0123 & 1.5334 & 0.03 & -56.43 & -10.17 \\
\hline \multicolumn{17}{|c|}{ Rural sites on the Chinese Loess Plateau or nearby ( 3 sites) } \\
\hline 10 & Mt. Gaolan & 0.58 & 0.14 & 2.03 & 0.16 & 0.03 & 0.13 & 0.36 & 0.81 & 0.64 & 0.89 & 0.0108 & 1.5154 & 0.04 & -59.36 & -20.87 \\
\hline 11 & Yulin & 0.53 & 0.15 & 2.05 & 0.11 & 0.03 & 0.08 & 0.32 & 0.84 & 0.72 & 0.89 & 0.0122 & 1.5070 & 0.03 & -56.81 & -9.09 \\
\hline \multirow[t]{2}{*}{12} & Datong & 0.35 & 0.13 & 2.15 & 0.19 & 0.09 & 0.10 & 0.58 & 1.15 & 0.83 & 0.86 & 0.0171 & 1.4905 & 0.09 & -107.86 & -13.71 \\
\hline & Average & 0.49 & 0.14 & 2.08 & 0.15 & 0.05 & 0.10 & 0.42 & 0.93 & 0.73 & 0.88 & 0.0134 & 1.5043 & 0.05 & -74.67 & -14.56 \\
\hline \multicolumn{17}{|c|}{ Rural sites in eastern China (15 sites) } \\
\hline 13 & Changde & 0.32 & 0.16 & 2.18 & 0.14 & 0.07 & 0.07 & 0.58 & 1.15 & 0.88 & 0.93 & 0.0101 & 1.4619 & 0.04 & -75.33 & -31.44 \\
\hline 14 & Dongtan & 0.37 & 0.16 & 2.12 & 0.17 & 0.08 & 0.09 & 0.62 & 1.21 & 0.86 & 0.93 & 0.0080 & 1.4624 & 0.04 & -79.41 & -33.18 \\
\hline 15 & Chun'an & 0.30 & 0.18 & 2.30 & 0.19 & 0.12 & 0.08 & 0.81 & 1.22 & 0.92 & 0.94 & 0.0066 & 1.4095 & 0.04 & -86.49 & -46.48 \\
\hline 16 & Huimin & 0.36 & 0.15 & 2.07 & 0.22 & 0.10 & 0.12 & 0.83 & 1.14 & 0.86 & 0.89 & 0.0147 & 1.4852 & 0.08 & -111.58 & -25.49 \\
\hline 17 & Lin'an & 0.29 & 0.17 & 2.24 & 0.21 & 0.12 & 0.09 & 0.87 & 1.29 & 0.91 & 0.93 & 0.0089 & 1.4172 & 0.06 & -93.09 & -41.73 \\
\hline 18 & Mt.Longfeng & 0.28 & 0.15 & 2.44 & 0.08 & 0.04 & 0.04 & 0.34 & 1.38 & 0.90 & 0.89 & 0.0165 & 1.4647 & 0.03 & -51.17 & -11.34 \\
\hline 19 & Fuyang & 0.29 & 0.17 & 2.28 & 0.21 & 0.13 & 0.09 & 0.89 & 1.31 & 0.92 & 0.94 & 0.0070 & 1.4147 & 0.05 & -91.69 & -42.29 \\
\hline 20 & Shangdianzi & 0.40 & 0.15 & 2.33 & 0.12 & 0.05 & 0.07 & 0.43 & 1.17 & 0.86 & 0.89 & 0.0148 & 1.4840 & 0.04 & -59.99 & -20.58 \\
\hline 21 & Yushe & 0.41 & 0.15 & 2.18 & 0.14 & 0.06 & 0.08 & 0.50 & 1.07 & 0.84 & 0.92 & 0.0090 & 1.4878 & 0.03 & -66.72 & -25.99 \\
\hline 22 & Dengfeng & 0.39 & 0.15 & 2.03 & 0.23 & 0.09 & 0.13 & 0.79 & 1.02 & 0.83 & 0.89 & 0.0131 & 1.4782 & 0.08 & -104.78 & -35.84 \\
\hline 23 & Huainan & 0.30 & 0.17 & 2.25 & 0.21 & 0.13 & 0.08 & 0.91 & 1.17 & 0.92 & 0.88 & 0.0166 & 1.4308 & 0.10 & -129.17 & -24.44 \\
\hline 24 & Jiande & 0.29 & 0.17 & 2.18 & 0.20 & 0.12 & 0.08 & 0.84 & 1.34 & 0.91 & 0.92 & 0.0099 & 1.4085 & 0.06 & -91.06 & -40.07 \\
\hline 25 & Tonglu & 0.29 & 0.17 & 2.20 & 0.20 & 0.12 & 0.08 & 0.83 & 1.31 & 0.91 & 0.93 & 0.0091 & 1.4269 & 0.06 & -89.82 & -41.28 \\
\hline 26 & Xiaoshan & 0.28 & 0.17 & 2.24 & 0.22 & 0.13 & 0.09 & 0.87 & 1.35 & 0.91 & 0.93 & 0.0082 & 1.4134 & 0.06 & -95.23 & -40.39 \\
\hline \multirow[t]{2}{*}{27} & Xiyong & 0.33 & 0.16 & 2.43 & 0.11 & 0.06 & 0.05 & 0.41 & 1.32 & 0.89 & 0.94 & 0.0074 & 1.4072 & 0.02 & -53.18 & -25.45 \\
\hline & Average & 0.33 & 0.16 & 2.23 & 0.18 & 0.09 & 0.08 & 0.70 & 1.23 & 0.89 & 0.92 & 0.0107 & 1.4435 & 0.05 & -85.25 & -32.40 \\
\hline \multicolumn{17}{|c|}{ Urban sites (23 sites) } \\
\hline 28 & Anshan & 0.36 & 0.17 & 2.24 & 0.26 & 0.12 & 0.14 & 0.94 & 1.12 & 0.86 & 0.89 & 0.0158 & 1.4759 & 0.10 & -117.99 & -39.66 \\
\hline 29 & Beijing-Nanjiao & 0.45 & 0.15 & 2.33 & 0.19 & 0.07 & 0.12 & 0.65 & 1.12 & 0.84 & 0.92 & 0.0100 & 1.4939 & 0.05 & -82.06 & -29.43 \\
\hline 30 & Beijing-CAMS & 0.50 & 0.16 & 2.37 & 0.19 & 0.07 & 0.12 & 0.65 & 1.12 & 0.79 & 0.90 & 0.0115 & 1.5108 & 0.05 & -72.66 & -29.10 \\
\hline 31 & Chengdu & 0.34 & 0.21 & 2.26 & 0.26 & 0.16 & 0.10 & 1.17 & 1.12 & 0.92 & 0.97 & 0.0033 & 1.4116 & 0.04 & -110.42 & -52.21 \\
\hline 32 & Dalian & 0.35 & 0.16 & 2.24 & 0.16 & 0.08 & 0.09 & 0.62 & 1.22 & 0.87 & 0.93 & 0.0095 & 1.4584 & 0.04 & -75.50 & -37.42 \\
\hline 33 & Fushun & 0.38 & 0.17 & 2.34 & 0.22 & 0.09 & 0.12 & 0.80 & 1.12 & 0.87 & 0.84 & 0.0244 & 1.4954 & 0.11 & -116.91 & -19.59 \\
\hline 34 & Hangzhou & 0.30 & 0.17 & 2.21 & 0.22 & 0.12 & 0.10 & 0.87 & 1.30 & 0.90 & 0.91 & 0.0109 & 1.4337 & 0.07 & -31.57 & -40.16 \\
\hline 35 & Hefei & 0.29 & 0.15 & 2.37 & 0.18 & 0.10 & 0.08 & 0.69 & 1.28 & 0.90 & 0.85 & 0.0195 & 1.4253 & 0.10 & -105.83 & -19.22 \\
\hline 36 & Jiaozuo & 0.35 & 0.16 & 2.17 & 0.20 & 0.10 & 0.10 & 0.76 & 1.14 & 0.88 & 0.91 & 0.0105 & 1.4722 & 0.05 & -92.29 & -39.35 \\
\hline 37 & Lanzhou & 0.54 & 0.14 & 2.04 & 0.28 & 0.06 & 0.22 & 0.66 & 0.81 & 0.66 & 0.83 & 0.0197 & 1.5193 & 0.10 & -126.17 & -13.81 \\
\hline 38 & Nanjing & 0.33 & 0.16 & 2.16 & 0.25 & 0.12 & 0.12 & 0.94 & 1.13 & 0.88 & 0.88 & 0.0154 & 1.4446 & 0.10 & -143.38 & -28.29 \\
\hline 39 & Nanning & 0.30 & 0.18 & 2.53 & 0.20 & 0.13 & 0.06 & 0.97 & 1.36 & 0.95 & 0.92 & 0.0107 & 1.4272 & 0.07 & -121.92 & -33.35 \\
\hline 40 & Panyu & 0.26 & 0.16 & 2.29 & 0.16 & 0.10 & 0.06 & 0.69 & 1.43 & 0.93 & 0.90 & 0.0137 & 1.4155 & 0.07 & -96.03 & -26.56 \\
\hline 41 & Shanghai & 0.40 & 0.15 & 1.93 & 0.19 & 0.08 & 0.11 & 0.68 & 1.10 & 0.84 & 0.88 & 0.0142 & 1.4814 & 0.07 & -106.89 & -24.34 \\
\hline 42 & Shenyang & 0.31 & 0.16 & 2.23 & 0.22 & 0.12 & 0.10 & 0.89 & 1.20 & 0.90 & 0.84 & 0.0253 & 1.4589 & 0.14 & -144.88 & -15.02 \\
\hline 43 & Tianjin & 0.42 & 0.16 & 2.26 & 0.23 & 0.10 & 0.13 & 0.83 & 1.11 & 0.86 & 0.89 & 0.0134 & 1.4957 & 0.07 & -108.09 & -33.26 \\
\hline 44 & Ürümqi & 0.48 & 0.14 & 2.14 & 0.15 & 0.04 & 0.10 & 0.42 & 0.93 & 0.75 & 0.85 & 0.0192 & 1.5371 & 0.05 & -70.55 & -11.74 \\
\hline 45 & Xi'an & 0.37 & 0.16 & 1.85 & 0.26 & 0.11 & 0.15 & 0.98 & 0.98 & 0.82 & 0.88 & 0.0150 & 1.4888 & 0.10 & -132.55 & -35.93 \\
\hline 46 & Yinchuan & 0.38 & 0.14 & 2.02 & 0.11 & 0.04 & 0.07 & 0.37 & 1.12 & 0.81 & 0.94 & 0.0054 & 1.4930 & 0.02 & -48.67 & -21.89 \\
\hline 47 & Zhengzhou & 0.43 & 0.18 & 2.22 & 0.28 & 0.12 & 0.16 & 0.99 & 1.10 & 0.86 & 0.95 & 0.0045 & 1.4626 & 0.04 & -101.10 & -46.18 \\
\hline 48 & Shijiazhuang & 0.40 & 0.16 & 2.28 & 0.26 & 0.12 & 0.14 & 0.95 & 1.09 & 0.87 & 0.88 & 0.0154 & 1.4754 & 0.09 & -125.05 & -33.66 \\
\hline 49 & Wuhan & 0.34 & 0.17 & 2.22 & 0.22 & 0.12 & 0.10 & 1.00 & 1.16 & 0.91 & 0.88 & 0.0196 & 1.4779 & 0.11 & -171.80 & -20.40 \\
\hline \multirow[t]{2}{*}{50} & Zhuzilin & 0.27 & 0.17 & 2.45 & 0.15 & 0.09 & 0.05 & 0.66 & 1.45 & 0.94 & 0.96 & 0.0049 & 1.4438 & 0.03 & -73.16 & -40.65 \\
\hline & Average & 0.37 & 0.16 & 2.22 & 0.21 & 0.10 & 0.11 & 0.79 & 1.15 & 0.86 & 0.90 & 0.0136 & 1.4695 & 0.07 & -103.28 & -30.05 \\
\hline
\end{tabular}

\footnotetext{
${ }^{a}$ Optical parameters at a wavelength of $440 \mathrm{~nm}$. ${ }^{\mathrm{b}}$ Ångström exponents between 440 and $870 \mathrm{~nm}$
} 
Author contributions. All authors contributed to shaping the ideas and reviewing the paper. $\mathrm{HC}, \mathrm{XX}$, and $\mathrm{XZ}$ designed and implemented the research and prepared the manuscript. HC, HZ, YW, and HW contributed to analysis of the CARSNET dataset. HC, XX, JZ, OD, BNH, PG, and ECA contributed to the CARSNET data retrieval. HC, BQ, WG, HY, RZ, LY, JC, YZ, KG, and XZ carried out the CARSNET observations. OD, BNH, PG, and ECA provided constructive comments on this research.

Competing interests. The authors declare that they have no conflict of interest.

Acknowledgements. This work was supported by grants from the National Science Fund for Distinguished Young Scholars (41825011), the National Key R\&D Program Pilot Projects of China (2016YFA0601901), National Natural Science Foundation of China (41590874), the CAMS Basis Research Project (2017Z011), the European Union Seventh Framework Programme (FP7/2007-2013) under grant agreement no. 262254, AERONET-Europe ACTRIS-2 program, and the European Union's Horizon 2020 research and innovation programme under grant agreement no. 654109.

Financial support. This research has been supported by the National Science Fund for Distinguished Young Scholars (grant no. 41825011), the National Key R \& D Program Pilot Projects of China (grant no. 2016YFA0601901), the National Natural Science Foundation of China (grant no. 41590874), the European Union's Horizon 2020 research and innovation programme (grant no. 654109), and the European Union Seventh Framework Programme (FP7/2007-2013).

Review statement. This paper was edited by Xiaohong Liu and reviewed by three anonymous referees.

\section{References}

Bi, J. R., Huang, J. P., Fu, Q., Wang, X., Shi, J. S., Zhang, W., Huang, Z. W., and Zhang, B. D.: Toward characterization of the aerosol optical properties over Loess Plateau of Northwestern China, J. Quant. Spectrosc. Ra., 112, 346-360, https://doi.org/10.1016/j.jqsrt.2010.09.006, 2011.

Bokoye, A. I., Royer, A., O’Neill, N. T., Cliche, P., Fedosejevs, G., Teillet, P. M., and Mcarthur, L. J. B.: Characterization of atmospheric aerosols across Canada from a Ground-based sun photometer network: Aerocan, Atmos. Ocean., 39, 429-456, https://doi.org/10.1080/07055900.2001.9649687, 2001.

Breon, F., Tanré, D., and Generoso, S.: Aerosols effect on the cloud droplet size monitored from satellite, Science, 295, 834-838, https://doi.org/10.1126/science.1066434, 2002.

Cao, J. J., Lee, S. C., Chow, J. C., Watson, J. G., Ho, K. F., Zhang, R. J., Jin, Z. D., Shen, Z. X., Chen, G. C., Kang, Y. M., Zou, S. C., Zhang, L. Z., Qi, S.H., Dai, M. H., Cheng, Y., and $\mathrm{Hu}, \mathrm{K}$. : Spatial and seasonal distributions of carbona- ceous aerosols over China, J. Geophys. Res., 112, D22S11, https://doi.org/10.1029/2006JD008205, 2007.

Charlson, R. J., Schwartz, S. E., Hales, J. M., Cess, D., Coakley, J. A., and Hansen, J. E.: Climate forcing by anthropogenic aerosols, Science, 255, 423-430, https://doi.org/10.1126/science.255.5043.423, 1992.

Che, H. Z., Shi, G. Y., Zhang, X. Y., Arimoto, R., Zhao, J. Q., Xu, L., Wang, B., and Chen, Z. H.: Analysis of 40 years of solar radiation data from China, 1961-2000, Geophys. Res. Lett., 32, L06803, https://doi.org/10.1029/2004GL022322, 2005.

Che, H., Shi, G., Uchiyama, A., Yamazaki, A., Chen, H., Goloub, P., and Zhang, X.: Intercomparison between aerosol optical properties by a PREDE skyradiometer and CIMEL sunphotometer over Beijing, China, Atmos. Chem. Phys., 8, 3199-3214, https://doi.org/10.5194/acp-8-3199-2008, 2008.

Che, H., Zhang, X., Chen, H., Damiri, B., Goloub, P., Li, Z., Zhang, X., Wei, Y., Zhou, H., Dong, F., Li, D., and Zhou, T.: Instrument calibration and aerosol optical depth (AOD) validation of the China Aerosol Remote Sensing Network (CARSNET), J. Geophys. Res., 114, D03206, https://doi.org/10.1029/2008JD011030, 2009a.

Che, H. Z., Zhang, X. Y., Alfraro, S., Chatenet, B., Gomes, L., and Zhao, J. Q.: Aerosol optical properties and its radiative forcing over Yulin, China in 2001 and 2002, Adv. Atmos. Sci., 26, 564576, https://doi.org/10.1007/s00376-009-0564-4, 2009b.

Che, H. Z., Yang, Z. F., Zhang, X. Y., Zhu, C. Z., Ma, Q. L., Zhou, H. G., and Wang, P.: Study on the aerosol optical properties and their relationship with aerosol chemical compositions over three regional background stations in China, Atmos. Environ., 43, 1093-1099, https://doi.org/10.1016/j.atmosenv.2008.11.010, 2009c.

Che, H., Xia, X., Zhu, J., Li, Z., Dubovik, O., Holben, B., Goloub, P., Chen, H., Estelles, V., Cuevas-Agulló, E., Blarel, L., Wang, H., Zhao, H., Zhang, X., Wang, Y., Sun, J., Tao, R., Zhang, X., and Shi, G.: Column aerosol optical properties and aerosol radiative forcing during a serious haze-fog month over North China Plain in 2013 based on ground-based sunphotometer measurements, Atmos. Chem. Phys., 14, 2125-2138, https://doi.org/10.5194/acp-14-2125-2014, 2014.

Che, H., Zhang, X.-Y., Xia, X., Goloub, P., Holben, B., Zhao, H., Wang, Y., Zhang, X.-C., Wang, H., Blarel, L., Damiri, B., Zhang, R., Deng, X., Ma, Y., Wang, T., Geng, F., Qi, B., Zhu, J., Yu, J., Chen, Q., and Shi, G.: Ground-based aerosol climatology of China: aerosol optical depths from the China Aerosol Remote Sensing Network (CARSNET) 2002-2013, Atmos. Chem. Phys., 15, 7619-7652, https://doi.org/10.5194/acp15-7619-2015, 2015.

Che, H., Qi, B., Zhao, H., Xia, X., Eck, T. F., Goloub, P., Dubovik, O., Estelles, V., Cuevas-Agulló, E., Blarel, L., Wu, Y., Zhu, J., Du, R., Wang, Y., Wang, H., Gui, K., Yu, J., Zheng, Y., Sun, T., Chen, Q., Shi, G., and Zhang, X.: Aerosol optical properties and direct radiative forcing based on measurements from the China Aerosol Remote Sensing Network (CARSNET) in eastern China, Atmos. Chem. Phys., 18, 405-425, https://doi.org/10.5194/acp18-405-2018, 2018.

Che, H., Gui, K., Xia, X., Wang, Y., Holben, B., Goloub, P., CuevasAgulló, E., Wang, H., Zheng, Y., Zhao, H., and Zhang, X.: Large contribution of meteorological factors to inter-decadal changes in 
regional aerosol optical depth, Atmos. Chem. Phys., 19, 1049710523, https://doi.org/10.5194/acp-19-10497-2019, 2019a.

Che, H., Xia, X., Zhao, H., Dubovik, O., Holben, B. N., Goloub, P., Cuevas-Agulló, E., Estelles, V., Wang, Y., Bing, J. Z., Wei, Q., Honglong, G., Renjian, Y., Leiku, Z., Jing, Y., Wang, C. H., Zheng, Y., Gui, K., Zhang, X., and Zhang, $\mathrm{X}$.: Datasets for "Spatial distribution of aerosol microphysical and optical properties and direct radiative effect from the China Aerosol Remote Sensing Network", figshare, Dataset, https://doi.org/10.6084/m9.figshare.9885128.v1, 2019b.

Cheng, T. T., Xu, C., Duan, J. Y., Wang, Y. F., Leng, C. P., Tao, J., Che, H. Z., He, Q. S., Wu, Y. F., Zhang, R. J., Li, X., Chen, J. M., Kong, L. D., and Yu, X. N.: Seasonal variation and difference of aerosol optical properties in columnar and surface atmospheres over Shanghai, Atmos. Environ., 123, 315-326, 2015.

Cong, Z. Y., Kang, S. C., Liu, X. D., and Wang, G. F.: Elemental composition of aerosol in the Nam Co region, Tibetan Plateau, during summer monsoon season, Atmos. Environ., 41, 11801187, https://doi.org/10.1016/j.atmosenv.2006.09.046, 2007.

Cong, Z. Y., Kang, S. C., Smirnov, A., and Holben, B.: Aerosol optical properties at $\mathrm{Nam} \mathrm{Co}$, a remote site in central Tibetan Plateau, Atmos. Res., 92, 42-48, https://doi.org/10.1016/j.atmosres.2008.08.005, 2009.

Duan, J. and Mao, J.: Study on the distribution and variation trends of atmospheric aerosol optical depth over the Yangtze River Delta, Acta Scien. Circum., 27, 537-543, https://doi.org/10.1007/978-1-4020-6475-3_126, 2007.

Dubovik, O. and King, M. D.: A flexible inversion algorithm for retrieval of aerosol optical properties from sun and sky radiance measurements, J. Geophys. Res., 105, 20673-20696, https://doi.org/10.1029/2000JD900282, 2000.

Dubovik, O., Holben, B. N., Eck, T. F., Smirnov, A., Kaufman, Y. J., King, M. D., Tanre, D., and Slutsker, I.: Variability of absorption and optical properties of key aerosol types observed in worldwide locations, J. Atmos. Sci., 59, 590-608, https://doi.org/10.1175/15200469(2002)059<0590:VOAAOP>2.0.CO;2, 2002.

Dubovik, O., Sinyuk, A., Lapyonok, T., Holben, B. N., Mishchenko, M., Yang, P., Eck, T. F., Volten, H., Munoz, O., Veihelmann, B., van der Zande, W. J., Leon, J. F., Sorokin, M., and Slutsker, I.: Application of spheroid models to account for aerosol particle nonsphericity in remote sensing of desert dust, J. Geophys. Res.Atmos., 111, D11208, https://doi.org/10.1029/2005JD006619, 2006.

Eck, T. F., Holben, B. N., Reid, J. S., Dubovik, O., Smirnov, A., O’Neill, N. T., Slutsker, I., and Kinne, S.: Wavelength dependence of the optical depth of biomass burning, urban, and desert dust aerosols, J. Geophys. Res., 104, 31333-31349, https://doi.org/10.1029/1999jd900923, 1999.

Eck, T. F., Holben, B. N., Dubovik, O., Smirnov, A., Goloub, P., Chen, H. B., Chatenet, B., Gomes, L., Zhang, X. Y., Tsay, S. C., Ji, Q., Giles, D., and Slutsker, I.: Columnar aerosol optical properties at AERONET sites in central eastern Asia and aerosol transport to the tropical Mid-Pacific, J. Geophys. Res., 110, D06202, https://doi.org/10.1029/2004JD005274, 2005.

Estellés, V., Campanelli, M., Utrillas, M. P., Expósito, F., and Martínez-Lozano, J. A.: Comparison of AERONET and SKYRAD4.2 inversion products retrieved from a Cimel
CE318 sunphotometer, Atmos. Meas. Tech., 5, 569-579, https://doi.org/10.5194/amt-5-569-2012, 2012.

Fan, X., Chen, H., Goloub, P., Xia, X., Zhang, W., and Chatenet, B.: Analysis of column-integrated aerosol optical thickness in Beijing from AERONET observations, China Part., 4, 330-335, https://doi.org/10.1016/s1672-2515(07)60285-1, 2006.

García, O. E., Díaz, J. P., Expósito, F. J., Díaz, A. M., Dubovik, O., Dubuisson, P., Roger, J.-C., Eck, T. F., Sinyuk, A., Derimian, Y., Dutton, E. G., Schafer, J. S., Holben, B. N., and García, C. A.: Validation of AERONET estimates of atmospheric solar fluxes and aerosol radiative forcing by groundbased broadband measurements, J. Geophys. Res., 113, D21207, https://doi.org/10.1029/2008JD010211, 2008.

García, O. E., Díaz, J. P., Expósito, F. J., Díaz, A. M., Dubovik, O., and Derimian, Y.: Aerosol radiative forcing: AERONET based estimates, climate Models, InTech, edited by: Druyan, L., ISBN 978-953-51-0135-2, 2012.

Garrett, T. J. and Zhao, C.: Increased Arctic cloud longwave emissivity associated with pollution from mid-latitudes, Nature, 440, 787-789, https://doi.org/10.1038/nature04636, 2006.

Gelencser, A.: Carbonaceous Aerosol, Atmospheric and Oceanographic Sciences Libery, vol. 30., Springer, Netherland, 2004.

Giles, D. M., Holben, B. N., Tripathi, S. N., Eck, T. F., Newcomb, W. W., Slutsker, I., Dickerson, R. R., Thompson, A. M., Mattoo, S., Wang, S., Singh, R. P., Sinyuk, A., and Schafer, J. S.: Aerosol properties over the Indo-Gangetic Plain: A mesoscale perspective from the TIGERZ experiment, J. Geophys. Res.-Atmos., 116, D18203, https://doi.org/10.1029/2011JD015809, 2011.

Giles, D. M., Holben, B. N., Eck, T. F., Sinyuk, A., Smirnov, A., Slutsker, I., Dickerson, R. R., Thompson, A. M., and Schafer, J. S.: An analysis of AERONET aerosol absorption properties and classifications representative of aerosol source regions, J. Geophys. Res.-Atmos., 117, 127-135, https://doi.org/10.1029/2012JD018127, 2012.

Gui, K., Che, H., Wang, Y., Wang, H., Zhang, L., Zhao, H., Zheng, Y., Sun, T., and Zhang, X.: Satellite-derived PM2.5 concentration trends over Eastern China from 1998 to 2016: Relationships to emissions and meteorological parameters, Environ. Pollut., 247, 1125-1133, https://doi.org/10.1016/j.envpol.2019.01.056, 2019.

Gobbi, G. P., Kaufman, Y. J., Koren, I., and Eck, T. F.: Classification of aerosol properties derived from AERONET direct sun data, Atmos. Chem. Phys., 7, 453-458, https://doi.org/10.5194/acp-7453-2007, 2007.

Goloub, P., Li, Z., Dubovik, O., Blarel, L., Podvin, T., Jankowiak, I., Lecoq, R., Deroo, C., Chatenet, B., and Morel, J. P.: PHOTONS/AERONET sunphotometer network overview: description, activities, results, Fourteenth International Symposium on Atmospheric and Ocean Optics/Atmospheric Physics, 6936, 69360V, https://doi.org/10.1117/12.783171, 2007.

Haywood, J. M. and Shine, K. P.: The effect of anthropogenic sulfate and soot aerosol on the clear sky planetary radiation budget, Geophys. Res. Lett., 22, 603-606, https://doi.org/10.1029/95GL00075, 1995.

He, Q., Li, C., Geng, F., Yang, H., Li, P., Li, T., Liu, D., and Pei, Z.: Aerosol optical properties retrieved from Sun photometer measurements over Shanghai, China, J. Geophys. Res.-Atmos., 117, D16204, https://doi.org/10.1029/2011JD017220, 2012.

Holben, B. N., Eck, T. F., Slutsker, I., Tanré, D., Buis, J. P., Setzer, A., Vermote, E., Reagan, J. A., Kaufman, Y. J., Naka- 
jima, T., Lavenu, F., Jankowiak, I., and Smirnov, A.: AERONET - A Federated Instrument Network and Data Archive for Aerosol Characterization, Remote Sens. Environ., 66, 1-16, https://doi.org/10.1016/S0034-4257(98)00031-5, 1998.

Jacobson, M. Z.: A physically based treatment of elemental carbon optics: implications for global direct forcing of aerosols, Geophys. Res. Lett., 27, 217-220, https://doi.org/10.1029/1999g1010968, 2000.

Lee, K. H., Li, Z., Cribb, M. C., Liu, J., Wang, L., Zheng, Y., Xia, X., Chen, H., and Li, B.: Aerosol optical depth measurements in eastern China and a new calibration method, J. Geophys. Res., 115, 4038-4044, https://doi.org/10.1029/2009JD012812, 2010.

Li, C. C., Mao, J. T., Lau, A. K. H., Chen, J. C., Yuan, Z. B., Liu, X. Y., Zhu, A. H., and Liu, G. Q.: Characteristics of distribution and seasonal variation of aerosol optical depth in eastern China with MODIS products, Chinese Sci. Bull., 48, 2488-2495, https://doi.org/10.1360/03wd0224, 2003.

Li, S., Wang, T., Xie, M., Han, Y., and Zhuang, B.: Observed aerosol optical depth and angstrom exponent in urban area of Nanjing, China, Atmos. Environ., 123, 350-356, https://doi.org/10.1016/j.atmosenv.2015.02.048, 2015.

Li, X. and Zhang, L.: Analysis of aerosol sources and optical properties based on backward trajectory method over SACOL, Acta Phys. Sin., 61, 1-9, https://doi.org/10.7498/aps.61.023402, 2012.

Li, Z., Chen, H., Cribb, M., Dickerson, R., Holban, B., Li, C., Lu, D., Luo, Y., Maring, H., Shi, G., Tsay, S. C., Wang, P., Wang, Y., Xia, X., and Zhao, F.: Overview of the East Asian Studies on tropospheric aerosols, an international regional experiment(EAST-AIRE), J. Geophys. Res., 112, D22S00, https://doi.org/10.1029/2007JD008853, 2007.

Li, Z., Lau, W. K.-M., Ramanathan, V., Wu, G., Ding, Y., Manoj, M. G., Liu, J., Qian, Y., Li, J., Zhou, T., Fan, J., Rosenfeld, D., Ming, Y., Wang, Y., Huang, J., Wang, B., Xu, X., Lee, S.S., Cribb, M., Zhang, F., Yang, X., Takemura, T., Wang, K., Xia, X., Yin, Y., Zhang, H., Guo, J., Zhai, P. M., Sugimoto, N., Babu, S. S., and Brasseur, G. P.: Aerosol and monsoon climate interactions over Asia, Rev. Geophys., 54, 866-929, https://doi.org/10.1002/2015RG000500, 2016.

Li, Z. Q., Eck, T., Zhang, Y., Zhang, Y. H., Li, D. H., Li, L., Xu, H., Hou, W. Z., Lv, Y., Goloub, P., and Gu, X. F.: Observations of residual submicron fine aerosol particles related to cloud and fog processing during a major pollution event in Beijing, Atmos. Environ., 86, 187-192, https://doi.org/10.1016/j.atmosenv.2013.12.044, 2014.

Li, Z. Q., Xu, H., Li, K. T., Li, D. H., Xie, Y. S., Li, L., Zhang, Y., Gu, X. F., Zhao, W., Tian, Q. J., Deng, R. R., Su, X. L., Huang, B., Qiao, Y. L., Cui, W. Y., Hu, Y., Gong, C. L., Wang, Y. Q., Wang, X. F., Wang, J. P., Du, W.B., Pan, Z. Q., Li, Z. Z., and Bu, D.: Comprehensive Study of Optical, Physical, Chemical, and Radiative Properties of Total Columnar Atmospheric Aerosols over China: An Overview of Sun-Sky Radiometer Observation Network (SONET) Measurements, B. Am. Meteorol. Soc., 99, 739-755, https://doi.org/10.1175/BAMS-D-17-0133.1, 2018.

Liu, C., Chung, C. E., and Yin, Y.: The absorption Ångström exponent of black carbon: From numerical aspects, Atmos. Chem. Phys., 18, 6259-6273, https://doi.org/10.5194/acp-2017836, 2018

Luo, Y., Lu, D., Zhou, X., and Li, W.: Analyses on the spatial distribution of aerosol optical depth over china in recent 30 years, Chinese Journal of Atmospheric Sciences, 26, 721-730, https://doi.org/10.1002/mop.10502, 2002.

Mai, B., Deng, X., Xia, X., Che, H., Guo, J., Liu, X., Zhu, J., and Ling, C.: Column-integrated aerosol optical properties of coarse- and fine-mode particles over the Pearl River Delta region in China, Sci. Total. Environ., 622-623, 481-492, https://doi.org/10.1016/j.scitotenv.2017.11.348, 2018.

Myhre, G.: Consistency between satellite-derived and modeled estimates of the direct aerosol effect, Science, 325, 187-190, https://doi.org/10.1126/science.1174461, 2009.

Nakajima, T. and Tanaka, M.: Algorithms for radiative intensity calculations in moderately thick atmospheres using a truncation approximation, J. Quant. Spectrosc. Ra., 40, 51-69, https://doi.org/10.1016/0022-4073(88)90031-3, 1988.

Pappalardo, G., Amodeo, A., Apituley, A., Comeron, A., Freudenthaler, V., Linné, H., Ansmann, A., Bösenberg, J., D’Amico, G., Mattis, I., Mona, L., Wandinger, U., Amiridis, V., AladosArboledas, L., Nicolae, D., and Wiegner, M.: EARLINET: towards an advanced sustainable European aerosol lidar network, Atmos. Meas. Tech., 7, 2389-2409, https://doi.org/10.5194/amt7-2389-2014, 2014

Prats, N., Cachorro, V. E., Berjón, A., Toledano, C., and De Frutos, A. M.: Column-integrated aerosol microphysical properties from AERONET Sun photometer over southwestern Spain, Atmos. Chem. Phys., 11, 12535-12547, https://doi.org/10.5194/acp-1112535-2011, 2011.

Qin, K., Wang, L. Y., Wu, L. X., Xu, J., Rao, L. L., Letu, H., Shi, T. W., and Wang, R. F.: A campaign for investigating aerosol optical properties during winter hazes over Shijiazhuang, China, Atmos. Res., 198, 113-122, https://doi.org/10.1016/j.atmosres.2017.08.018, 2017.

Ramanathan, V., Crutzen, P. J., Kiehl, J. T., and Rosenfeld, D.: Aerosol, climate, and hydrological cycle, Science 294, 21192124, https://doi.org/10.1126/science.1064034, 2001.

Remer, L. A. and Kaufman, Y. J.: Dynamic aerosol model: Urban/industrial aerosol, J. Geophys. Res., 103, 13859-13871, https://doi.org/10.1029/98jd00994, 1998.

Russell, P. B., Bergstrom, R. W., Shinozuka, Y., Clarke, A. D., DeCarlo, P. F., Jimenez, J. L., Livingston, J. M., Redemann, J., Dubovik, O., and Strawa, A.: Absorption Angstrom Exponent in AERONET and related data as an indicator of aerosol composition, Atmos. Chem. Phys., 10, 1155-1169, https://doi.org/10.5194/acp-10-1155-2010, 2010.

Schuster, G. L., Dubovik, O., and Arola, A.: Remote sensing of soot carbon - Part 1: Distinguishing different absorbing aerosol species, Atmos. Chem. Phys., 16, 1565-1585, https://doi.org/10.5194/acp-16-1565-2016, 2016 .

Schuster, G. L., Dubovik, O., Arola, A., Eck, T. F., and Holben, B. N.: Remote sensing of soot carbon - Part 2: Understanding the absorption Ångström exponent, Atmos. Chem. Phys., 16, 15871602, https://doi.org/10.5194/acp-16-1587-2016, $2016 \mathrm{~b}$.

Shen, L., Zhao, C., Ma, Z., Li, Z., Li, J., and Wang, K.: Observed decrease of summer sea-land breeze in Shanghai from 1994 to 2014 and its association with urbanization, Atmos. Res., 227, 198-209, https://doi.org/10.1016/j.atmosres.2019.05.007, 2019.

Shettle, E. P. and Fenn, R. W.: Models for the aerosols of the lower atmosphere and the effects of humidity variations on their optical properties. AFCRL Tech. Rep. 79 0214, Air Force Cambridge 
Research Laboratory, Hanscom Air Force Base, MA, 100 pp., 1979.

Stamnes, K., Tsay, S. C., Wiscombe, W., and Jayaweera, K.: Numerically stable algorithm for discrete-ordinate-method radiative transfer in multiple scattering and emitting layered media, Appl. Optics, 27, 2502-2509, https://doi.org/10.1364/ao.27.002502, 1988.

Su, X. L., Wang, Q., Li, Z. Q., Calvello, M., Esposito, F., Pavese, G., Lin, M. J., Cao, J. J., Zhou, C. Y., Li, D. H., and $\mathrm{Xu}, \mathrm{H}$. : Regional transport of anthropogenic pollution and dust aerosols in spring to Tianjin - A coastal megacity in China, Sci. Total Environ., 584-585, 381-392, https://doi.org/10.1016/j.scitotenv.2017.01.016, 2017.

Sun, J. Y., Zhang, Q., Canagaratna, M. R., Zhang, Y. M., Ng, N. L., Sun, Y. L., Jayne, J. T., Zhang, X. C., Zhang, X. Y., and Worsnop, D. R.: Highly time- and size-resolved characterization of submicron aerosol particles in Beijing using an Aerodyne Aerosol Mass Spectrometer, Atmos. Environ., 44, 131-140, 2010.

Sun, T., Che, H., Qi, B., Wang, Y., Dong, Y., Xia, X., Wang, H., Gui, K., Zheng, Y., Zhao, H., Ma, Q., Du, R., and Zhang, $\mathrm{X}$.: Aerosol optical characteristics and their vertical distributions under enhanced haze pollution events: effect of the regional transport of different aerosol types over eastern China, Atmos. Chem. Phys., 18, 2949-2971, https://doi.org/10.5194/acp18-2949-2018, 2018.

Takamura, T. and Nakajima, T.: Overview of SKYNET and its activities, Opt. Pura Apl., 37, 3303-3308, 2004.

Tao, R., Che, H. Z., Chen, Q. L., Wang, Y. Q., Sun, J. Y., Zhang, X. C., Lu, S., Guo, J. P., Wang, H., and Zhang, X. Y.: Development of an integrating sphere calibration method for Cimel sunphotometers in China aerosol remote sensing network, Particuology, 13, 88-99, https://doi.org/10.1016/j.partic.2013.04.009, 2014a.

Tao, R., Che, H., Chen, Q., Tao, J., Wang, Y., Sun, J., Wang, H., and Zhang, X.: Study of aerosol optical properties based on ground measurements over Sichuan Basin, China, Aerosol. Air. Qual. Res., 14, 905-915, https://doi.org/10.4209/aaqr.2013.04.0125, 2014b.

Twomey, S. A., Piepgrass, M., and Wolfe, T. L.: An assessment of the impact of pollution on the global cloud albedo, Tellus, 36B, 356-366, https://doi.org/10.1111/j.16000889.1984.tb00254.x, 1984.

Wan, X., Kang, S. C., Wang, Y. S., Xin, J. Y., Liu, B., Guo, Y. H., Wen, T. X., Zhang, G. S., and Cong, Z. Y.: Size distribution of carbonaceous aerosols at a high-altitude site on the central Tibetan Plateau (Nam Co Station, 4730m a.s.1.), Atmos. Res., 153, 155-164, https://doi.org/10.1016/j.atmosres.2014.08.008, 2015.

Wang, L. C., Gong, W., Xia, X. A., Zhu, J., Li, J., and Zhu, Z. M.: Long-term observations of aerosol optical properties at Wuhan, an urban site in Central China, Atmos. Environ., 101, 94-102, https://doi.org/10.1016/j.atmosenv.2014.11.021, 2015.

Wang, P., Che, H. Z., Zhang, X. C., Song, Q. L., Wang, Y. Q., Zhang, Z. H., Dai, X., and Yu, D. J.: Aerosol optical properties of regional background atmosphere in Northeast China, Atmos. Environ., 44, 4404-4412, https://doi.org/10.1016/j.atmosenv.2010.07.043, 2010.

Wang, X., Huang, J. P., Ji, M. X., and Higuchi, K.: Variability of east Asia dust events and their long-term trend, Atmos. Environ., 42, 3156-3165, https://doi.org/10.1016/j.atmosenv.2007.07.046, 2007.
Wang, Z., Liu, D., Wang, Y., Wang, Z., and Shi, G.: Diurnal aerosol variations do affect daily averaged radiative forcing under heavy aerosol loading observed in Hefei, China, Atmos. Meas. Tech., 8, 2901-2907, https://doi.org/10.5194/amt-8-2901-2015, 2015.

Wehrli, C.: Calibration of filter radiometers for the GAW Aerosol Optical Depth network at Jungfraujoch and Mauna Loa, in: Proceedings of ARJ Workshop, SANW Congress, Davos, Switzerland, 70-71, 2002.

Whitey, K. T.: The physical characteristics of sulfur aerosols, Atmos. Environ., 41, 25-49, https://doi.org/10.1016/j.atmosenv.2007.10.057, 1978.

Wu, Y. F., Zhang, R. J., Pu, Y. F., Zhang, L. M., Ho, K. F., and Fu, C. B.: Aerosol optical properties observed at a semi-arid rural site in Northeastern China, Aerosol Air. Qual. Res., 12,503-514, https://doi.org/10.4209/aaqr.2011.11.0202, 2012.

Xia, C., Sun, J. Y., Qi, X. F., Shen, X. J., Zhong, J. T., Zhang, X. Y., Wang, Y. Q., Zhang, Y. M., and Hu, X. Y.: Observational study of aerosol hygroscopic growth on scattering coefficient in Beijing: A case study in March of 2018, Sci. Total Environ., 685, 239$247,2019$.

Xia, X.: A closer looking at dimming and brightening in China during 1961-2005, Ann. Geophys., 28, 1121-1132, https://doi.org/10.5194/angeo-28-1121-2010, 2010.

Xia, X., Chen, H., Goloub, P., Zong, X., Zhang, W., and Wang, P.: Climatological aspects of aerosol opticalproperties in North China Plain based on ground and satellite remote-sensing data, J. Quant. Spectrosc. Ra., 127, 12-23, https://doi.org/10.1016/j.jqsrt.2013.06.024, 2013.

Xie, C., Nishizawa, T., Sugimoto, N., Matsui, I., and Wang, Z.: Characteristics of aerosol optical properties in pollution and Asian dust episodes over Beijing, China. Appl. Opt., 47, 49454951, https://doi.org/10.1364/AO.47.004945, 2008.

Xie, S., Liu, X., Zhao, C., and Zhang, Y.: Sensitivity of CAM5-Simulated Arctic Clouds and Radiation to Ice Nucleation Parameterization, J. Climate, 26, 5981-5999, https://doi.org/10.1175/jcli-d-12-00517.1, 2013.

Xin, J., Wang, Y., Li, Z. Q., Wang, P. C., Hao, W. M., Nordgren, B. L., Wang, S. G., Liu, G. R., Wang, L. L., Wen, T. X., Sun, Y., and Hu, B.: Aerosol optical depth (AOD) and Ångström exponent of aerosols observed by the Chinese Sun Hazemeter Network from August 2004 to September 2005, J. Geophys. Res., 112, D05203, https://doi.org/10.1029/2006JD007075, 2007.

Xin, J., Wang, Y., Pan, Y., Ji, D., Liu, Z., Wen, T. X., Wang, Y. H., Li, X. R., Sun, Y., Sun, J., Wang, P. C., Wang, G. H., Wang, X. M., Cong, Z. Y., Song, T., Hu, B., Wang, L. L., Tang, G. Q., Gao, W. K., Guo, Y. H., Miao, H. Y., Tian, S. L., and Wang, L.: The campaign on atmospheric aerosol research network of China: CARE-China, B. Am. Meteorol. Soc., 96, 1137-1155, https://doi.org/10.1175/BAMS-D-14-00039.1, 2015.

Xin, J. Y., Wang, L. L., Wang, Y. S., Li, Z., and Wang, P.: Trends in aerosol optical properties over the Bohai Rim in Northeast China from 2004 to 2010, Atmos. Environ., 45, 6317-6325, https://doi.org/10.1016/j.atmosenv.2011.08.052, 2011.

Yang, X., Zhao, C., Zhou, L., Wang, Y., and Liu, X.: Distinct impact of different types of aerosols on surface solar radiation in China, J. Geophys. Res.-Atmos., 121, 6459-6471, https://doi.org/10.1002/2016jd024938, 2016.

Yang, X., Zhao, C., Zhou, L., Li, Z., Cribb, M., and Yang, S.: Wintertime cooling and a potential connection with transported 
aerosols in Hong Kong during recent decades, Atmos. Res., 211, 52-61, https://doi.org/10.1016/j.atmosres.2018.04.029, 2018.

Yang, Y., Zhao, C., Dong, X., Fan, G., Zhou, Y., Wang, Y., Zhao, L., Lv, F., and Yan, F.: Toward understanding the process-level impacts of aerosols on microphysical properties of shallow cumulus cloud using aircraft observations, Atmos. Res., 221, 27-33, https://doi.org/10.1016/j.atmosres.2019.01.027, 2019a.

Yang, Y., Zhao, C., Sun, L., and Wei, J.: Improved aerosol retrievals over complex regions using NPP Visible Infrared Imaging Radiometer Suite observations, Earth. Space. Sci., 6, https://doi.org/10.1029/2019ea000574, 2019b.

Yuan, Y., Shuai, Y., Li, X. W., Liu, B., and Tan, H. P.: Using a new aerosol relative optical thickness concept to identify aerosol particle species, Atmos. Res., 150, 1-11, https://doi.org/10.1016/j.atmosres.2014.07.007, 2014.

Zhang, L., Sun, J. Y., Shen, X. J., Zhang, Y. M., Che, H., Ma, Q. L., Zhang, Y. W., Zhang, X. Y., and Ogren, J. A.: Observations of relative humidity effects on aerosol light scattering in the Yangtze River Delta of China, Atmos. Chem. Phys., 15, 84398454, https://doi.org/10.5194/acp-15-8439-2015, 2015.

Zhang, M., Ma, Y., Gong, W., Liu, B., Shi, Y., and Chen, Z.: Aerosol optical properties and radiative effects: Assessment of urban aerosols in central China using 10-year observations, Atmos. Environ., 182, 275-285, https://doi.org/10.1016/j.atmosenv.2018.03.040, 2018.

Zhang, R., Jing, J., Tao, J., Hsu, S.-C., Wang, G., Cao, J., Lee, C. S. L., Zhu, L., Chen, Z., Zhao, Y., and Shen, Z.: Chemical characterization and source apportionment of $\mathrm{PM}_{2.5}$ in Beijing: seasonal perspective, Atmos. Chem. Phys., 13, 7053-7074, https://doi.org/10.5194/acp-13-7053-2013, 2013.

Zhao, C., Lin, Y., Wu, F., Wang, Y., Li, Z., Rosenfeld, D., and Wang, Y.: Enlarging Rainfall Area of Tropical Cyclones by Atmospheric Aerosols, Geophys. Res. Lett., 45, https://doi.org/10.1029/2018gl079427, 2018

Zhao, C., Wang, Y., Shi, X., Zhang, D., Wang, C., Jiang, J. H., Zhang, Q., and Fan, H.: Estimating the contribution of local primary emissions to particulate pollution using highdensity station observations, J. Geophys. Res.-Atmos., in press, https://doi.org/10.1029/2018jd028888, 2019.

Zhao, H., Che, H., Ma, Y., Xia, X., Wang, Y., Wang, P., and $\mathrm{Wu}, \mathrm{X}$.: Temporal variability of the visibility, particulate matter mass concentration and aerosol optical properties over an urban site in Northeast China, Atmos. Res., 166, 204-212, https://doi.org/10.1016/j.atmosres.2015.07.003, 2015.
Zhao, H., Che, H., Wang, Y., Wang, H., Ma, Y., and Wang, Y.: Investigation of the Optical Properties of Aerosols over the Coastal Region at Dalian, Northeast China, Atmosphere, 7, 103, https://doi.org/10.3390/atmos7080103, 2016.

Zhao, H., Che, H., Xia, X., Wang, Y., Wang, H., Wang, P., Ma, Y., Yang, H., Liu, Y., Wang, Y., Gui, K., Sun, T., Zheng, Y., and Zhang, X.: Multi-year ground-based measurements of aerosol optical properties and direct radiative effect over different surface types in northeastern China, J. Geophys. Res.-Atmos., 123, 13887-13916, https://doi.org/10.1029/2018JD029141, 2018.

Zhang, K., Zhao, C., Fan, H., Yang, Y., and Sun, Y.: Toward Understanding the Differences of PM2.5 Characteristics Among Five China Urban Cities, Asia-Pac., J. Atmos. Sci., in press, https://doi.org/10.1007/s13143-019-00125-w, 2019.

Zheng, C., Zhao, C., Zhu, Y., Wang, Y., Shi, X., Wu, X., Chen, T., Wu, F., and Qiu, Y.: Analysis of influential factors for the relationship between $\mathrm{PM}_{2.5}$ and AOD in Beijing, Atmos. Chem. Phys., 17, 13473-13489, https://doi.org/10.5194/acp-17-134732017, 2017.

Zheng, Y., Che, H., Xia, X., Wang, Y., Wang, H., Wu, Y., Tao, J., Zhao, H., An, L., Li, L., Gui, K., Sun, T., Li, X., Sheng, Z., Liu, C., Yang, X., Liang, Y., Zhang, L., Kuang, X., Luo, S., and You, Y.: Five-year observation of aerosol optical properties and its radiative effects to planetary boundary layer during air pollution episodes in North China: Intercomparison of a plain site and a mountainous site in Beijing, Sci. Total Environ., 674, 140-158, 2019.

Zhu, J., Che, H., Xia, X., Chen, H. B., Goloub, P., and Zhang, W.: Column-integrated aerosol optical and physical properties at a regional background atmosphere in North China Plain, Atmos. Environ., 84, 54-64, https://doi.org/10.1016/j.atmosenv.2013.11.019, 2014.

Zhuang, B., Wang, T., Li, S., Liu, J., Talbot, R., Mao, H., Yang, X., Fu, C., Yin, C., Zhu, J., Che, H., and Zhang, X.: Optical properties and radiative forcing of urban aerosols in Nanjing over China, Atmos. Environ., 83, 43-52, https://doi.org/10.1016/j.atmosenv.2013.10.052, 2014. 